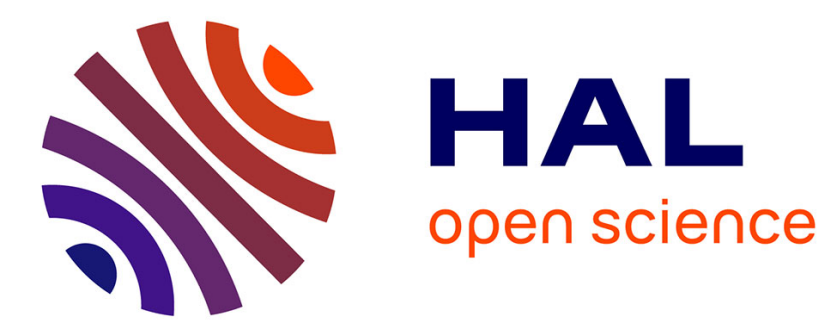

\title{
Glutathionylation primes soluble GAPDH for late collapse into insoluble aggregates
}

\author{
Mirko Zaffagnini, Christophe H. Marchand, M. Malferrari, Samuel Murail, \\ Sara Bonacchi, Damiano Genovese, Marco Montalti, G. Venturoli, G. Falinii, \\ Marc Baaden, et al.
}

\section{To cite this version:}

Mirko Zaffagnini, Christophe H. Marchand, M. Malferrari, Samuel Murail, Sara Bonacchi, et al.. Glutathionylation primes soluble GAPDH for late collapse into insoluble aggregates. Proceedings of the National Academy of Sciences of the United States of America, 2019, 116 (51), pp.26057-26065. 10.1073/pnas.1914484116 . hal-02370717

\section{HAL Id: hal-02370717 https://hal.science/hal-02370717}

Submitted on 19 Nov 2019

HAL is a multi-disciplinary open access archive for the deposit and dissemination of scientific research documents, whether they are published or not. The documents may come from teaching and research institutions in France or abroad, or from public or private research centers.
L'archive ouverte pluridisciplinaire $\mathbf{H A L}$, est destinée au dépôt et à la diffusion de documents scientifiques de niveau recherche, publiés ou non, émanant des établissements d'enseignement et de recherche français ou étrangers, des laboratoires publics ou privés. 


\section{Glutathionylation primes soluble GAPDH for late collapse into insoluble aggregates}

Zaffagnini1,* M., Marchand² C.H., Malferrari1,3 M., Murail4 S., Bonacchi3 S., Genovese ${ }^{3}$ D.,

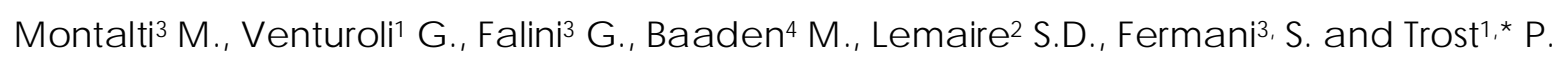

1Department of Pha macy and Biotechnology, University of Bologna, Ita ly

2Laboratoire de Biologie Moléculaire et Cellulaire des Eucaryotes, UMR8226 Centre National de la Recherche Scientifique, Sorbonne Université, Institut de Biologie PhysicoChimique, Paris, France

3Department of Chemistry "G. Ciamician", University of Bologna, Italy

4Laboratoire de Biochimie Théorique, UPR9080 Centre National de la Recherche Sc ientifique, Université Paris Diderot, Sorbonne Paris Cité, Paris, France

*Correspondence should be addressed to M.Z (mirko.zaffagnini3@unibo.it), and to P.T. (paolo.trost@unibo.it) 


\section{ABSTRACT}

Protein aggregation is a complex physiological process, primarily detemined by stressrelated factors revealing the hidden aggregation propensity of proteins that otherwise are fully soluble. Here we report a mechanism by which glycolytic glyceraldehyde-3phosphate dehydrogenase of Arabidopsis thaliana (AtGAPC 1) is primed to form insoluble aggregates by the glutathionylation of its catalytic cysteine (Cys149). Following a lag phase, glutathionylated AtGAPC1 initiates a self-aggregation process resulting in the formation of branched chains of globular partic les made of partia lly misfolded and totally inactive proteins. GSH molecules within AtG APC 1 active sites a re suggested to provide the initial destabilizing signal. The following removal of glutathione by the formation of an altemative disulfide bond between Cys149 and Cys153 reinforces the aggregation process. Besides acting as a protective mechanism against overoxidation, $S$ glutathionylation of AtGAPC1 triggers an unexpected aggregation pathway with completely different and still unexplored physiological implic ations. 


\section{INTRODUCTION}

A single polypeptide chain may adopt a huge number of different conformations among which only one, or a few, are biologically active. Although native conformations are themodynamically favored, in some proteins they are separated from non-native conformations by small energy ba miers' ${ }^{1,2}$. Misfolded proteins typic ally expose hydrophobic residues that are buried in native confomations and these residues tend to promote protein aggregation in aqueous environments. Aggregation propensity is highly differentiated among different proteins, depending on their amino acid sequence and post-translational modifications, but still, the capability to aggregate can be considered as an intrinsic property of any type of polypeptide ${ }^{1,3}$.

Protein aggregates may occur in different shapes ${ }^{1,4}$. In some cases, protein aggregation starts with the formation of small oligomers and ends up with amyloid fibrils characterized by a typic al cross beta-sheet architec ture. Several human disorders collec tively known as amyloidoses are associated with amyloid depositions made of disease-specific proteins associated in fibrils. Different from amyloid fibrils, protein particulates are insoluble oligomers with a globular shape and no cross beta-sheet architecture as they are formed by proteins that are only partially unfolded ${ }^{4}$. Aggregation-prone proteins tend to form partic ulates at $\mathrm{pH}$ close to their isoelectric point, and amyloid fibrils at $\mathrm{pH}$ values in which they bear a strong net charge ${ }^{6}$. Both aggregation products are considered states that virtually any protein can be forced to adopt, though the process might require harsh treatments such as heat or extreme $\mathrm{pH}$ values ${ }^{6}$.

The risk of protein aggregation in vivo is exacerbated by the high concentration of proteins in living cells ${ }^{3}$. Being at high risk of aggregation, proteins that are particularly abundant tend to adopt conformations that result in higher solubility compared to less abundant ones. Moreover, cells of any domain of life possess a large set of molecular chaperones that limit protein aggregation by shielding the exposed hydrophobic patches of misfolded proteins, thereby promoting their refolding8-10. However, in spite of the molecular chaperones and the efficiency of the whole machinery that controls proteome homeostasis, hundreds of proteins remain at high risk of aggregation, even under nonpathological conditions. In vivo, protein aggregates have been reported in different model organisms including E. coli ${ }^{11}$, yeast ${ }^{12,13}$, C. elegans ${ }^{14,15}$, tomato and tobacco cell c ultures ${ }^{16,17}$, typically as a consequence of aging or heat stress. These protein aggregates are not associated with specific diseases while they may be associated with oxidative stress conditions shared by different types of stress $^{13}$. Oxidative post-translational 
modific ations (Cys and Met oxidation, carbonylation, etc.) have been shown to favour protein aggregation, presumably by lowening the energy bamiers separating native from misfolded conformations ${ }^{18-21}$. Although in some cases non-amyloid protein aggregation can induce cell death ${ }^{22,23}$, protein aggregation may also be beneficial to cells as long as sequestration of aggregates in specific cell sites prevents toxicity ${ }^{24}$. Indeed, non-amyloid protein aggregates may be asymmetrically inherited by daughter cells ${ }^{25}$, dissolved by chaperones ${ }^{12,26}$ or digested by proteases ${ }^{27}$ or autophagy ${ }^{28,29}$. All these processes limit cell toxic ity. In this sense, protein aggregation may be considered as a last line of defence a ga inst stress².

Glyceraldehyde-3-phosphate dehydrogenase (GAPDH) is a ubiquitous and abundant glycolytic enzyme, which was found to aggregate in different types of cells and c onditions. In vitro, a nimal GAPDH forms aggregates under strongly oxida tive conditions ${ }^{21-}$ 23,30-34. The essential catalytic cysteine of GAPDH can be oxidized by $\mathrm{H}_{2} \mathrm{O}_{2}$ to generate a sulfenic acid group that may either react with a second $\mathrm{H}_{2} \mathrm{O}_{2}$ molecule to form a sulfinic acid. Altematively, the sulfenic acid of the catalytic cysteine can react with a second thiol, like that of reduced glutathione (GSH), to form a mixed disulfide (Sglutathionylation) ${ }^{35,36}$. While the sulfinic acid cannot be reduced by cell reductants, the glutathionylated cysteine can be reduced back to the thiol group by glutaredoxins or thioredoxins 37,38 .

The sensitivity of GAPDH to reactive oxygen species (ROS) has important consequences. Since the interaction between cytoplasmic GAPDH (GAPC) and autophagy-related protein 3 (ATG3) negatively regulates autophagy, ROS may induce autophagy in plants by impaing GAPC-ATG3 complex formation ${ }^{39}$. On the other hand, oxidized GAPC activates phospholipase $D$ at the plasma membrane creating a connection between ROS- and lipid-signaling that controls Arabidopsis response to stress ${ }^{40}$. In animal cells, GAPDH sensitivity to $\mathrm{H}_{2} \mathrm{O}_{2}$ was proposed to have a positive role in oxidative stress conditions because it allows rerouting of the primary metabolism from glycolysis to the oxidative pentose phosphate pathway, the resulting NADPH being essential for the antioxidant response, which in tum allows GAPDH recovery ${ }^{41}$. Thanks to its extreme redox sensitivity, both in animals and in plants ${ }^{42,43}, \mathrm{GAPDH}$ is now regarded as being a hub of controlled redox responses for metabolic regulation ${ }^{44}$.

Clearly, all functional interactions, catalytic activity and regulatory functions of GAPDH are impaired by aggregation. In Arabidopsis plants, GAPC is suggested to form aggregates in leaves infiltrated with flg22, a pathogen-associated molecular pattem that 
triggers basal immunity with ROS being implicated in the response ${ }^{32}$. Here we show that Arabidopsis GAPC1 specifically aggregates in vitro following oxidation by $\mathrm{H}_{2} \mathrm{O}_{2}$ in the presence of GSH at nearly physiologic al concentrations. These conditions lead to specific glutathionylation of GAPC 1 catalytic cysteines with no other a mino acids being modified. Though protected from irreversible oxidation, glutathionylated GAPC 1 is conformationally destabilized and, surprisingly, slowly induced to aggregate into oligomeric particles. In the next phase, gluta thionylated GAPC 1 spontaneously releases GSH and the small oligomeric particles melt into large micrometric clusters made of smaller (pseudo) globular units. Aggregated GAPC 1 is partially unfolded and bears a novel disulfide bond engaging the catalytic Cys149 and the conserved Cys153 of the same subunits. Formation of the disulfide bond speeds up the aggregation process. The crystal structure of glutathionylated AtGAPC1 and Molecular Dynamics (MD) calculations derived thereof, provide clues on the mechanism by which a physiological post-translational modification like S-glutathionylation may trigger the collapse of a soluble tetrameric protein into insoluble aggregates.

\section{RESULTS}

\section{AtGAPC1 may form non-amyloid aggregates}

Visible light scattering (turbidity) can be taken as a proxy of protein stability in solution, and turbidity measurements show that native AtGAPC 1 in solution $(0.2 \mathrm{mg} / \mathrm{ml})$ is stable for hours at room temperature (Fig. 1a). Similar behavior was shown in the presence of $\mathrm{H}_{2} \mathrm{O}_{2}$ $(125 \mu \mathrm{M})$ at 25:1 ratio with AtGAPC1 subunits (Fig. 1a), whereas addition of GSH together with $\mathrm{H}_{2} \mathrm{O}_{2}$ (5:1 ratio) caused a dramatic increase in turbidity overtime, indicative of protein aggregation (Fig. 1a). The increase in turbidity followed a lag-phase of 15-20 min (Fig. 1a, inset), and proceeded linearly for more than one hour reaching a plateau in about 2 hours (Fig. 1a).

The formation of products with increasing size was confimed by dynamic light scattering (DLS) measurements, from which information about the size of the aggregates may be derived from autocorrelation functions. By fitting the autocorrelation function to a spherical model, a hydrodynamic diameter $\left(d_{H}\right)$ of $9.2 \pm 0.5 \mathrm{~nm}$ was calculated for soluble 
AtGAPC 1 (Fig. 1b). This value did not change over time and upon treatment with $\mathrm{H}_{2} \mathrm{O}_{2}$ alone (Fig. 1b), and was compatible with the crystal structure of AtGAPC1 tetramers ${ }^{45}$. On the other hand, aggregates formed after 90 min incubation with $\mathrm{H}_{2} \mathrm{O}_{2}$ and $\mathrm{GSH}$ were -200-fold larger in tems of hydrodynamic diameter (Fig. 1b), thus roughly corresponding to the volume of 10 million AtG APC 1 tetramers.

Protein aggregates could be dissolved by SDS at $95{ }^{\circ} \mathrm{C}$ and migrated in reducing polyacrylamide gels as a single band corresponding to AtGAPC1 monomers (Fig. Sla). Under non-reducing conditions, the protein profile in SDS-PAGE was almost identical, except for a minor band likely corresponding to AtG APC 1 tetramers (Fig. Sla).

Inspection of AtGAPC1 aggregates by transmission and scanning electron microscopy (TEM and SEM, respectively) revealed irregular shapes resulting from the random binding of nearly globular particles of $\sim 300-500 \mathrm{~nm}$ (Fig. 1c and Fig. 1d). No fibrils were observed. Fluorescence spectroscopy demonstrated that AtGAPC 1 aggregates could interact with dyes commonly used to stain beta-enriched regions (Thioflavin-T, ThT) and hydrophobic patches (1-Anilino-8-Naphthalene Sulfonate, ANS) in protein aggregates (Fig. S1b and Fig. S1c, respectively). Native AtGAPC 1, on the other hand, showed minimal interaction with either ThT or ANS dyes, suggesting that the conformation of AtGAPC 1 in the aggregates was different from the native one.

A detailed analysis of secondary structure elements in both native and aggregated AtGAPC 1 was performed by Fourier-transform infrared spectroscopy (FIR). In order to test the method, the amide I band of native AtGAPC 1 was decomposed into five Gaussian curves corresponding to different sec ondary structure motifs a cc ording to the literature ${ }^{46,47}$ (Fig. S2a). The relative content of a-helices $\left(1654 \mathrm{~cm}^{-1}\right)$ and $\beta$-sheets $\left(1637 \mathrm{~cm}^{-1}\right)$ was in good agreement with crystallographic data (Fig. 1e). Additionally, the absence of a Gaussian component at $1645 \mathrm{~cm}^{-1}$ was fully consistent with the absence of disordered regions in native AtGAPC1 structure. The same measurements performed on AtGAPC 1 aggregates showed an amide I band of different shape (Fig. S2c). The amide I difference spectrum between the two forms (Fig. $\mathbf{5 2 b}$ ) exhibited an increase of absomtion at wavenumbers higher than $1665 \mathrm{~cm}^{-1}$, paralleled by a decrease between 1665 and 1625 $\mathrm{cm}^{-1}$. The decomposition of the amide I band showed two major effects consisting in a 3fold decrease of a-helices and a 4-fold increase in short structural motifs ( $\beta$-tums and $310^{-}$ helic es; 1669 and $1660 \mathrm{~cm}^{-1}$ in native and aggregated protein, respectively), suggesting a conversion of the former into the latter ones (Fig. 1f). No clear changes were observed in other spectral components including unstruc tured regions $\left(1645 \mathrm{~cm}^{-1}\right)$ and $\beta$-sheets (1636 
$\mathrm{cm}^{-1}$ ), the latter result suggesting that AtGAPC 1 aggregates do not contain the cross- $\beta$ sp ine typical of a myloid-like fibrils ${ }^{48,49}$.

\section{Aggregating AtGAPC1 is transiently glutathionylated}

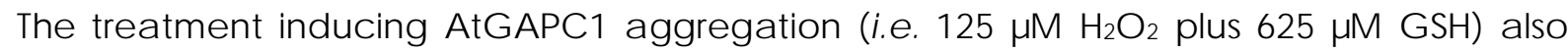
determined a rapid and complete inactivation of protein activity (Fig. $\mathbf{2 a}$ ). Complete enzyme inactivation was attained in about 15 min and during this time, the inhibition of AtGAPC 1 could be efficiently reverted by the thiol reducing agent dithiothreitol (DTT) (Fig. 2b). However, DTT became less and less effective over time and after 90 min incubation with $\mathrm{H}_{2} \mathrm{O}_{2}$ and $\mathrm{GSH}$, only $25 \%$ of AtGAPC 1 activity could be recovered by the reductive treatment (Fig. 2b).

A detailed analysis by DLS, with light scattered intensity measured over 100 seconds intervals during the whole 90 min experiment, provided further hints on the aggregation process that paralleled the progressive, irreversible inactivation of AtGAPC1. The autocorrelation function, averaged over 500 seconds intervals, clearly demonstrated a slow increase of particle sizes during the first 25 min of the experiment (Fig. 2c and Fig $\mathbf{5 3 a}$ ) followed by rapid growth in the micrometric range till the end of the experiment (Fig. $\mathbf{2 c}$ ). The integrated count rate ( $\mathrm{kpcs}$ ), which depends on both the concentration and the size of the aggregates, showed a similarprofile (Fig. $\mathbf{2 c}$ ). Combination of the plots $(\mathbf{F i g} . \mathbf{2 c})$ thus suggests that AtGAPC 1 is first induced to self-assemble into small nanoparticles that only later start to melt into larger mic rometric aggregates.

MALDI-TOF mass spectrometry (MS) analysis showed that AtGAPC1 was transiently glutathionylated during the aggregation process. A large portion of AtGAPC1 ( $75 \%$ ) became glutathionylated after only 10 min of treatment with $\mathrm{H}_{2} \mathrm{O}_{2}$ and $\mathrm{GSH}$ ( $1 \mathrm{GSH} /$ monomer, Fig. 2d and Fig. $\mathbf{5 3 b}$ ) and reached $\sim 85 \%$ after 30 min incubation (Fig. 2d and Fig. S3b). However, after 90 min incubation, glutathionylation decreased to roughly 10\% (Fig. 2d and Fig. $\mathbf{5 3 b}$ ) and dropped to zero if the MS analysis was carried out on the insoluble aggregates obtained by centrifugation (Fig. S3c).

In princ iple, the sulfur atom of GSH could have been attacked by either a water molecule or by a thiol. In the latter case, the nucleophilic thiol could either belong to a second GSH molecule or to Cys153, the only other cysteine of AtGAPC 1. In order to solve the query, tryptic peptides were obtained from AtGAPC1 aggregates and a nalyzed by MADI-TOF MS. The presence of an intramolecular disulfide bond between Cys149 and Cys153 (Fig. 
2e) clearly demonstrated that the removal of GSH was the consequence of the nucleophilic attack performed by Cys153 of the same subunit on the proximal sulfur atom of gluta thionylated Cys149.

Overall, the plots of Figure 2 (panel a-d) hence describe a scenario in which AtGAPC1 is rapidly and reversibly inactivated by glutathionylation of Cys149 and slowly induced to self-assemble into small nanoparticles that later rapidly melt into larger micrometric aggregates. During this massive aggregation phase, inhibition of enzyme activity becomes permanent (not reverted by DTT) and glutathionylation of Cys149 is progressively substituted by a Cys149-Cys153 disulfide bond.

\section{Structural snapshots along the pathway to AtGAPC1 aggregation}

With the aim of describing the early steps of protein aggregation at the structural level, the crystal structure of AtGAPC 1 was determined after treatments with $\mathrm{H}_{2} \mathrm{O}_{2}$ alone or $\mathrm{H}_{2} \mathrm{O}_{2}$ plusGSH.

Inhibition of AtGAPC 1 activity by $\mathrm{H}_{2} \mathrm{O}_{2}$ alone is even faster than under glutathionylating conditions $\left(\mathrm{H}_{2} \mathrm{O}_{2}\right.$ plus GSH) (Fig. S4a and Fig. 2), and is irreversible (Fig. $\mathbf{S 4 b}$ ). This fast and irreversible kinetics indic ates that the first oxidation product of catalytic Cys149 (sulfenic acid) is short-lived because it further reacts with $\mathrm{H}_{2} \mathrm{O}_{2}$ to generate more oxidized forms (sulfinic or sulfonic acids). Fully oxidized AtGAPC1 remains, however, fully soluble and tetrameric (Fig. 1a, Fig. 1b, and Fig. S4c).

After soaking AtGAPC 1 crystals with $\mathrm{H}_{2} \mathrm{O}_{2}$, the effect of the oxidant could be directly evaluated from X-ray diffraction analysis and model structure calculations. The computed electron density map of $\mathrm{H}_{2} \mathrm{O}_{2}$-oxidized AtGapC 1 showed a clear positive density in the $F_{0}$ $F_{c}$ map around the thiol group of catalytic Cys149. In this additional electron density, a sulfinic acid or sulfinate $\left(-\mathrm{SO}_{2} \mathrm{H}\right.$ or $\left.-\mathrm{SO}_{2}{ }^{-}\right)$was easily built (Fig. S4d), in agreement with recent quantum-mechanical analyses ${ }^{45}$. Interestingly, no additional positive electron densities were observed for other $\mathrm{H}_{2} \mathrm{O}_{2}$-sensitive residues, i.e. neither for the second cysteine (Cys153) nor for the seven methionines of each subunit (Fig. S5). This observation demonstrates the absolute selectivity of $\mathrm{H}_{2} \mathrm{O}_{2}$ for ca talytic Cys149 a mong all other residues of AtGAPC 1 in these conditions.

Crysta ls of AtG APC 1 were also soaked with a solution containing both $\mathrm{H}_{2} \mathrm{O}_{2}$ and GSH (1:10 ratio) with the aim of attempting a glutathionylation reaction in crystallo. Again, soaked crystals were subjected to X-ray diffraction a nalysis and the 3D structure was solved at 3.0 
$\AA$ resolution (Fig. 3a). The calculated $F_{0}-F_{c}$ electron density map revealed, in both chains $\mathrm{O}$ and $\mathrm{R}$ of the asymmetric unit, an elongated positive electron density stemming from the thiol group of Cys149, which could be interpreted as a mixed disulfide bond with a glutathione molecule (Fig. 3b). Additional, discontinuous, electron density regions were ascribed to the carboxylic groups of bound GSH (Fig. 3b). Beyond the mixed disulfide bond, GSH was stabilized by hydrogen bonds with the protein, the NAD+ cofactor and the sulfate ions bound to the active site ( $P_{s}$ and $P_{i}$ sites) ${ }^{35}$ (Fig. 3b). Consistent with the results with $\mathrm{H}_{2} \mathrm{O}_{2}$-Soaked crystals, no other residues than Cys149 were modified by the treatment with $\mathrm{GSH}$ and $\mathrm{H}_{2} \mathrm{O}_{2}$. Therefore, even in the crystal, AtGAPC 1 may undergo the specific glutathionylation of $\mathrm{Cys} 149$ in the presence of $\mathrm{H}_{2} \mathrm{O}_{2}$ and $\mathrm{GSH}$ indicating that, under these conditions, sulfenic Cys149 (formed by the reaction of the thiol with $\mathrm{H}_{2} \mathrm{O}_{2}$ ) reacts faster with $\mathrm{GSH}$ than with $\mathrm{H}_{2} \mathrm{O}_{2}$, thereby escaping the irreversible modific ation.

Each GAPDH tetramer can bind a maximum of four GSH molecules lying at the entrance of the four active sites (Fig. 3a). However, GSH molecules did not occupy all the available sites in AtGAPC 1 crystals and were charac terized by high themal parameters. Indeed, the GSH occupancy (q) was $82 \%$ for chain $O$ and $67 \%$ for chain $\mathrm{R}$, and themal parameters (B) ranged between 60 and $80 \AA^{2}$, indicating substantial mobility of the GSH molecules within AtGAPC 1 a ctive sites.

Multiple molecular dynamics (MD) simulations, starting from the crystal structure of glutathionylated AtGAPC1 confimed the high mobility of bound GSH. Six main conformational clusters of the gluta thione were observed (Fig. S6) with only one (cluster 2) corresponding closely to the starting crystal structure. Glutathionylation of Cys 149 had no significant effect on the overall conformation of AtGAPC 1 tetramers within the crystal $\left(0.45 \AA\right.$ msd on $C_{a}$ atoms between glutathionylated and native AtGAPC 1$)$ and the average distance between the $S$ atoms of Cys149 and Cys153 remained prohibitive for the formation of a disulfide (8.7 $\AA$; Fig. 3b). This result is consistent with the fact that the protein was crystallized before undergoing glutathionylation.

MD simulations indicated, however, that glutathionylation had an impact on the intersulfur distance between Cys149 and Cys153. The modific ation clearly extends the range of inter-sulfur distances, sampling both shorter and longer distances compared to the $8.8 \AA$ of the native/reduced form (Fig. $\mathbf{3 c}$ and $\mathbf{F i g}$. $\mathbf{5 3 d}$ ). A strong correlation between the intercysteine distances and a metric combining key dihedral angles included between Cys149 and Cy153 was found (Fig. 3d), with a marked influence of the redox state. The overall conformational distribution of secondary structure elements analyzed by principal 
component analysis (PCA) showed that glutathionylation of Cys149 modified the protein conformational landscape and its plasticity by inducing a change in inter-domain arrangement (Fig. 3e). These changes observed on a microsecond timescale may represent the early stages of a local unfolding process that selectively prompted the protein to evolve towards an aggregation-prone conformation. Because of the subtle nature of the effects and the restricted timescale that can be sampled, quantitatively linking our observations to the formation of the Cys149-Cys153 disulfide and to the aggregation process on a much longer timescale remains, however, an important challenge.

\section{The relevance of the Cys 149-Cys 153 disulfide bond for aggregation}

The relevance of the Cys149-Cys153 disulfide bond for aggregation of AtGAPC1 was tested by chemical and genetic modific ations. Preventing disulfide formation by mutating Cys149 into Ser had the effect of inhibiting both AtGAPC 1 activity 45 and its aggregation propensity in the presence of $\mathrm{H}_{2} \mathrm{O}_{2}$ and $\mathrm{GSH}$ (Fig. 4a). A similar effect was obtained when AtGAPC 1 was pre-treated with the cysteine-alkylating agent iodoacetamide (IAM; Fig. 4a). Since IAM specifically alkylates Cys14937, this result confirms once again that aggregation is triggered by glutathionylation of Cys149, but provides no information on the role of the Cys149-Cys153 disulfide bond in the aggregation process. Mutation of Cys153 into Ser had, in contrast, no effect on enzyme activity and reversible inhibition by $\mathrm{H}_{2} \mathrm{O}_{2}$ and $\mathrm{GSH}$ (Fig. 57a and Fig. 57b). The C 1535 mutant was extensively glutathionylated after a 30 min incubation with $\mathrm{H}_{2} \mathrm{O}_{2}$ and GSH (Fig. 4b and Fig. 57c) and, in sharp contrast to wild type AtGAPC1, glutathionylation was stable over time, confirming the role of Cys153 in deglutathionylation (Fig. 4b and Fig. 57c). Interestingly, turbidity measurements showed that the aggregation kinetics of mutant C 1535 was 3.5-fold slower than that of wild type AtGAPC1 (Fig. S7d), in spite of the lag phase of similar duration (Fig. $\mathbf{4 c}$ and $\mathbf{F i g .}$ 4d). DLS analysis showed that both count rate increase (kcps; Fig. 4e) and particle size increase $\left(d_{H}\right.$; Fig. 4f) were significantly lower in the mutant compared to the wild type protein. Clearly, impaining the formation of the Cys149-Cys153 disulfide bond had a negative effect on the aggregation process. Conversely, the formation of the Cys149Cys153 disulfide bond sped up the process and promoted the growth of larger aggregates. 


\section{DISCUSSION}

In this work, we describe a mechanism by which an abundant tetrameric protein like GAPC 1 from Arabidopsis thaliana is primed to form insoluble oligomeric aggregates (protein particulates) by the specific glutathionylation of its catalytic cysteine.

Due to its acidic and nucleophilic catalytic cysteine (Cys149), AtGAPC 1 reacts quickly with $\mathrm{H}_{2} \mathrm{O}_{2}$. Cys149 thiolate $\left(-\mathrm{S}^{-}\right)$is first converted to a sulfenic acid intermediate $(-\mathrm{SOH})$ and then to sulfinic acid $\left(-\mathrm{SO}_{2}{ }^{-}\right)^{45}$. The modification of Cys149 by $\mathrm{H}_{2} \mathrm{O}_{2}$ is specific and irreversibly inhibits enzyme activity. The only other cysteine of AtGAPC 1 (Cys153), which is found strictly conserved in GAPDH enzymes from almost all living organisms ${ }^{41}$, is less exposed to the solvent and remains reduced even after long incubations with $\mathrm{H}_{2} \mathrm{O}_{2}$. This residue, which is $8.8 \AA$ apart from Cys149 in terms of inter-sulfur distance, does not react with sulfenic Cys149 either. In vitro, the two-step oxidation of Cys149 thiolate to the sulfinic acid proceeds undisturbed even at AtGAPC $1: \mathrm{H}_{2} \mathrm{O}_{2}$ equimolar concentrations ${ }^{45}$. In vivo, however, in the presence of millimolar concentrations of glutathione ${ }^{50}$, AtGAPC1 in Arabidopsis ${ }^{51}$, and orthologues in other photosynthetic organisms (Synechocystis sp. PCC680352; Chlamydomonas reinhardtii53) are found glutathionylated under oxidative stress conditions. This observation indic ates that sulfenic Cys149 may react faster with GSH than with $\mathrm{H}_{2} \mathrm{O}_{2}$. Effic ient interference of GSH on AtGAPC 1 irreversible oxidation apparently relies on the easy accommodation of glutathione within AtGAPC 1 active sites where it can be stabilized by several interactions with the protein, as derived from our crystal structure of glutathionylated AtGAPC1 (Fig. 3a and Fig. 3b). From its preferential position, GSH may attack sulfenic Cys149 leaving no possibility for $\mathrm{H}_{2} \mathrm{O}_{2}$ to compete. As long as the activity of glutathionylated GAPC can be recovered by cytoplasmic glutaredoxins or thioredoxins ${ }^{37}$, the resulting glutathionylation/deglutathionylation cycle perfectly fits into the metabolic remodelling of aerobic cells under oxidative stress conditions. Observations made on different types of a erobic cells show indeed that (i) $\mathrm{H}_{2} \mathrm{O}_{2}$ may inhibit glycolysis by inactivating GAPDH; (ii) the cell antioxidative response consumes NADPH for protective (recycling) functions including GAPDH deglutathionylation; and (iii) the pentose phosphate pathway and, only in plants, non-phosphorylating GAPDH, both activated by low NADPH levels, provide the NADPH required $35,41,44,54$.

Although proposed as a salvage pathway for redox-sensitive GAPDH, here we show that glutathionylation destabilizes AtGAPC 1 conformation and, in the long run, promotes the formation of insoluble aggregates. 
Aggregation of AtGAPC1 develops as a three-phase process. Glutathione is quite mobile when it is covalently bound to Cys149, but it interacts with the protein and affects its dynamics, both globally and locally, as clearly shown by MD simulations (Fig. 3d and Fig. 3e). These changes are indicative of a conformational evolution whose effects need tens of minutes to show up. In our hands, AtGAPC 1 could stay glutathionylated for about 10 min without changing signific antly its overall native conformation. In this "pre-aggregation phase", enzyme activity can be fully recovered upon removal of GSH by reduction (glutathionylation/deglutathionylation cycle) ${ }^{38}$.

True aggregation starts only later, during the "oligomeric phase". In this phase, the DTT efficiency in recovering the AtGAPC1 activity starts to decline, indicating that oligomenization is associated with a permanently inactivated state of the protein. In principle, this effect may suggest that the protein is misfolded and no more active, or altematively, that AtGAPC 1 active sites are inaccessible to DT because of initial aggregation. The "oligomeric phase" ends up with the completion of the lag phase of the whole aggregation process.

In the third phase, much faster than the previous one, partic les abruptly start to grow to reach micrometric dimensions. Final aggregates are made by hundreds of bead-like partic les of roughly $500 \mathrm{~nm}$ in $d_{H}\left(\approx 10^{5}\right.$ tetramers). Particle units are linked together to form irregular branched chains. During this "partic ulate phase", AtG APC1 loses its glutathionyl moiety in favour of a Cys149-Cys153 disulfide. This is a hallmark of an initial conformational shift. Otherwise, the formation of the Cys149-Cys153 disulfide would be prevented by the long inter-sulfur distance and unsuitable orientation of the side chains of the two cysteines that, in native AtGAPC1, are fixed into the rigid structure of a a-helix (Fig. S3d). Once formed, the disulfide must be instrumental for aggregation, as suggested by the slower and limited aggregation of the C153S mutant. The conformational modification undergone by aggregated AtGAPC1 is documented by the (limited) change in secondary structures revealed by FIR (Fig. 1e, Fig. 1f, and Fig. S2) and by the increased exposition of hydrophobic regions that bind ANS (Fig. S1c). The binding of ThT (Fig. S1b), documented by an increase in fluorescence that is orders of magnitude lower than that shown by amyloid fibrils ${ }^{4}$, is in agreement with the absence of a FIR positive signal ascribable to inter-chain $\beta$-struc tures $\left(1620 \mathrm{~cm}^{-1}\right)$, thus excluding the possibility of a cross- $\beta$ sheet a rc hitec ture typical of amyloids. On the other hand, the lack of unstructured regions (1645 $\mathrm{cm}^{-1}$ ) and the maintenance of secondary structures overall, seem to exclude the possibility that aggrega tes are fully disordered and a morphous. 
Shape and features of AtGAPC1 aggregates are reminiscent of animal GAPDH aggregates obtained after non-specific oxidation by the nitric oxide donor NOR321-23, although more than 15 different residues of GAPDH, including cysteines, methionines, and tyrosines, were found modified by the NOR3 treatment ${ }^{21}$. Aggregates contained intermolecular disulfides that bound together a minor portion of GAPDH subunits21,22. These aggregates, grown in vitro following a nucleated process under strongly oxidizing conditions, are thought to recapitulate the GAPDH aggregates observed in vivo in different pathologic al conditions (e.g. Alzheimer, Parkinson, ALS) 34,55,56 and under oxida tive stress ${ }^{23}$. Plants' GAPC is also extremely sensitive to oxida tive stress and a common target of redox post-translational modifications ${ }^{35}$, but to our knowledge, the only report of cytoplasmic GAPC aggregation deals with Arabidopsis plants treated with the flagellin fragment flg $22^{32}$. The flg 22 is a pathogen-associated molecular pattem that elicits basal immunity and ROS production and causes GAPC-GFP to coalesce into cytoplasmic fluorescent puncta that are indic ative of protein aggregation.

Globular particulates like those formed by glutathionylated AtGAPC1 are also formed by other aggregation-prone proteins under conditions that promote aggregation 4,6,57,58. Often protein particulates are made of proteins only partially unfolded. As a rule, they do not contain cross $\beta$-sheets, but the involvement of $\beta$-sheets and hydrophobic interactions in the aggregate formation are suggested by ThTand ANS binding.

In conclusion, here we show that a common thiol-based post-translational modification that occurs under oxidative stress conditions and consists in the addition of a glutathionyl moiety to a nucleophilic cysteine previously oxidized by $\mathrm{H}_{2} \mathrm{O}_{2}$, can trigger the formation of insoluble protein aggregates. This effect was studied in AtGAPC 1, the major glycolytic GAPDH isoform of Arabidopsis thaliana, and was found to primarily depend on two cysteines (Cys149, Cys153) that are highly conserved in GAPDHs of any source. The collapse of AtGAPC1 into insoluble particles can be efficiently counteracted by GSH removal, but if AtGAPC1 remains glutathionylated for too long, aggregation proceeds undisturbed until all the protein collapses into micrometric globular particles. The whole process primarily depends on catalytic Cys149 that needs to be first oxidized and then glutathionylated. The prompt oxidation of Cys149 by $\mathrm{H}_{2} \mathrm{O}_{2}$ is assisted by $\mathrm{Cys} 153$ in a mechanism that favours metabolic remodelling of oxidatively stressed yeast cells ${ }^{41}$. Interestingly, fully conserved Cys153 is shown here to assist also the aggregation process. Whether AtGAPC1 aggregates are dead-end products of oxidation that cells need to 
bioRxiv preprint first posted online Feb. 15,2019 ; doi: http://dx.doi.org/10.1101/545921. The copyright holder for this preprint (which was not peer-reviewed) is the author/funder, who has granted bioRxiv a license to display the preprint in perpetuity.

All rights reserved. No reuse allowed without permission.

dispose of or whether the native protein might be recovered by disassembling the partic ulates remains a n open question. 


\section{RG URE LEGENDS}

\section{Figure 1. Oxidative treatments alter AtGAPC1 stability inducing globularaggregation.}

(a) Turbidity analyses monitored at Abs405 of AtGAPC $1(5 \mu M)$ incubated with $\mathrm{H}_{2} \mathrm{O}_{2}$ in the absence (grey closed circles) or presence of GSH (black closed circles). In the control experiment, change in turbidity was measured following incubation of AtGAPC 1 in buffer alone (open circles). The turbidity of control and $\mathrm{H}_{2} \mathrm{O}_{2}$-treated AtGAPC1 showed no variation over $90 \mathrm{~min}$ while glutathionylated AtGAPC1 has a lag phase (15-20 min) followed by a rapid increase reaching a plateau after $2 \mathrm{~h}$ incubation. Data correspond to the mean of three biological experiments. (b) Dynamic light scattering (DLS) measurement of AtGAPC1 incubated for $90 \mathrm{~min}$ in the presence of buffer alone (white bar), $\mathrm{H}_{2} \mathrm{O}_{2}$ (grey bar), or $\mathrm{H}_{2} \mathrm{O}_{2}$ supplemented with $\mathrm{GSH}$ (black bar). No appreciable variation of protein diameter $\left(\mathrm{d}_{\mathrm{H}}\right)$ was observed for control and $\mathrm{H}_{2} \mathrm{O}_{2}$-treated AtGAPC 1 whilst glutathionylated AtGAPC1 formed aggregates with a diameter of $\sim 2 \mu \mathrm{m}$. This value might be underestimated due to technical limitations of the DLS instrument linked to the polydispersity index of samples. Data represent mean \pm s.d., $n=3$ experiments with technical duplicates; ${ }^{* *} P<0.01$. Representative TEM (c) and SEM (d) images of aggregated AtGAPC 1 obtained after 90 min incubation in the presence of $\mathrm{H}_{2} \mathrm{O}_{2}$ and GSH. (Scale bars: $5 \mu \mathrm{m}$ and $0.5 \mu \mathrm{m}$ ). (e) Relative content in secondary structures of native AtGAPC 1 determined by FIR analysis. FIR spectra were acquired after $\mathrm{H}_{2} \mathrm{O}$ to $\mathrm{D}_{2} \mathrm{O}$ substitution achieved through exhaustive concentrating/diluting steps. (f) Relative content in secondary structures of aggregated AtG APC 1 detemined by FIR a nalysis. The protein sample was incubated for 90 min in the presence of $\mathrm{H}_{2} \mathrm{O}_{2}$ and $\mathrm{GSH}$ and after treatment, the sample was centrifuged and the pellet resuspended in $\mathrm{D}_{2} \mathrm{O}$. In panels (e) and (f), the percentages of secondary structures derived from the crystallographic 3D-structure of native AtG APC 1 are also indicated as dashed lines.

\section{Figure 2. AtGAPC1 aggregation is specifically induced by tansient S-glutathionylation}

(a) Inactivation kinetics of AtGAPC 1 in the presence of $\mathrm{H}_{2} \mathrm{O}_{2}$ and GSH. Treatment of AtGAPC 1 with $\mathrm{H}_{2} \mathrm{O}_{2}$ and $\mathrm{GSH}$ causes a rapid inactivation with a complete loss of protein activity after $15 \mathrm{~min}$. Data represent mean \pm s.d., $n=3$ experiments with technical duplic ates. (b) Time-course DTT-dependent reactivity of inactivated AtGAPC1. At different 
time points, AtGAPC 1 samples treated with $\mathrm{H}_{2} \mathrm{O}_{2}$ and $\mathrm{GSH}$ were further incubated with DTT to assess the inactivation reversibility, which was found to be strictly dependent on incubation times. Data represent mean \pm s.d., $n=3$ experiments with tec hnic al duplic a tes. (c) Time-course DLS analysis of AtGAPC 1 treated with $\mathrm{H}_{2} \mathrm{O}_{2}$ and GSH. Protein diameters $\left(\mathrm{d}_{\mathrm{H}}, \mathrm{closed}\right.$ black circles) and integrated count rates ( $\mathrm{kpcs}$, open circles) were monitored over time and plotted versus time (0-90 $\mathrm{min})$. Data correspond to the mean of three biologic al experiments. (d) Time-dependent MADI-TOF signals of AtG APC 1 treated with $\mathrm{H}_{2} \mathrm{O}_{2}$ and GSH. Percentage of glutathionylated (i.e. $\sim 300$ Da shifted, closed circles) versus native (SH) or oxidized other than glutathionylated ( $\mathrm{Sox}_{\mathrm{x}}$ ) (open circles) AtGAPC 1 forms were extrapolated from MALDI-TOF spectra and plotted versus times $(0,10,30$, and 90 min). Data represent mean \pm s.d. $(n=3)$. (e) Peptide analysis of aggregated AtGAPC 1 . Following 90 min treatment with $\mathrm{H}_{2} \mathrm{O}_{2}$ and $\mathrm{GSH}$, the protein was centrifuged and the pellet was resuspended, subjected to tryptic digestion and analysed by mass spectrometry ana lysis prior and a fter trea tment with DTT.

\section{Figure 3. Structural features and MD simulation of S-glutathionylated AtGAPC1}

(a) Cartoon representation of AtGAPC 1 tetramer struc ture with four glutathione (GTTin the figure) molecules covalently bound to the catalytic cysteines and four cofactor molecules $\left(\mathrm{NAD}^{+}\right)$non-covalently interacting with the protein. Glutathione (GTT) and NAD+ molecules are shown as sticks. (b) Representation of the mixed disulfide bond between the catalytic cysteine (Cys149) and glutathione. The hydrogen bonds between glutathione and the protein (cut-off distance $3.5 \AA$ ) as well as the $2 F_{o}-F_{c}$ electron density map (contoured at $1.5 \sigma)$ around the Cys149 and glutathione, are shown. The distance between the sulfur atoms of Cys149 and 153 is only slightly shorter in glutathionylated AtG APC 1 with respect to the unmodified protein (Fig. S3d). The interactions between GSH and sulfate ions $\left(P_{s}\right.$ and $\mathrm{P}_{\mathrm{i}}$ sites) were omitted to mimic the solution environment (c) MD simulation-based analysis of distance distributions between the two sulfur atoms of Cys149 and Cys153 in reduced and glutathionylated forms are shown in blue and red colour, respectively. The distributions highlight the impact of gluta thionylation on the cysteines 149-153 distance. (d) Correlation of a metric combining several key angles with the distance between the two sulfur atoms of cysteines 149 and 153, contour of the lowest density for the glutathionylated and reduced forms are indicated by a red and blue contour, respectively. (e) Principal component analysis (PCA) applied to the whole MD simulation dataset of GAPC1 in reduced and glutathionylated form. Projection of third (y-axis) and 
eighth (x-axis) PCA modes computed on protein secondary structure regions. An overall density contour plot for the whole simulation set consolidating the data on all four cha ins is displayed as blue and red pla in lines for reduced and gluta thionyla ted forms, respectively. Crystal structure principal component projections are indicated as coloured dots. The probability distribution of both PCA modes is shown above and to the right of the corresponding contour plot axes, respectively. Crystal structure projection on both modes are indic ated ascoloured dots.

\section{Figure 4. Effect of Cys153 and Cys149 on AtGAPC1 aggregation process}

(a) DLS analysis of aggregation state of AtGAPC1 WT (WT), C149S mutant, and IAMpretreated AtGAPC1 WT (WT-IAM) following 90 min incubation in the presence of buffer alone or $\mathrm{H}_{2} \mathrm{O}_{2}$ supplemented with GSH. While AtGAPC1 WT increased in size $(\sim 2 \mu \mathrm{M}$ diameter), neither C149S mutant nor IAM-treated WT underwent an alteration of their tetrameric folding state. Data represent mean \pm s.d., $n=3$ experiments with technical duplic ates. (b) Time-dependent MALDI-TOF signals of $\mathrm{C} 153 \mathrm{~S}$ treated with $\mathrm{H}_{2} \mathrm{O}_{2}$ and GSH. Percentage of glutathionylated (i.e. $\sim 300 \mathrm{Da}$ shifted, closed blue circles) versus native (not shifted, open blue circles) C 1535 forms were extrapolated from MADI-TOF spectra and plotted versus times $(0,10,30$, and $90 \mathrm{~min})$. Data represent mean \pm s.d. $(n=3)$. (c) Turbidity analyses of AtGAPC 1 WT and $\mathrm{C} 153 \mathrm{~S}$ mutant incubated with $\mathrm{H}_{2} \mathrm{O}_{2}$ and GSH. Compared to WT, the turbidity of C153S showed a similar lag phase (15-20 min) but a much slower increase. Data represent mean \pm s.d., $n=3$ experiments with technical duplicates. (d) Turbidity kinetic s of AtG APC 1 WT and C 1535 (black and blue bar, respectively) expressed as milliAbs405/min as derived by panel c. Data represent mean \pm s.d., $n=3$ experiments with technical duplicates. (e-f) Time-dependent DLS analysis of AtGAPC 1 WT and C153S mutant treated with $\mathrm{H}_{2} \mathrm{O}_{2}$ and $\mathrm{GSH}$. Integrated count rates (kcps) and protein diameter $\left(d_{H}\right)$ of AtGAPC 1 WT (closed black circle) and C 1535 (closed blue circles) a re shown in the panel (e) and (f), respectively. Data represent mean \pm s.d., $n=3$ experiments with technical duplic ates. 


\section{ONUNE METHODS}

\section{Reagents}

Unless otherwise indicated, chemicals were from Sigma-Aldrich. $\mathrm{H}_{2} \mathrm{O}_{2}$ was quantified spectrophotometric a lly using a molar extinc tion coeffic ient at $240 \mathrm{~nm}$ of $43.6 \mathrm{M}^{-1} \mathrm{~cm}^{-1}$.

Expression and purification of recombinant GAPDH from Arabidopsis thaliana. pET28a (+) expression vectors carying the coding sequence for wild-type Arabidopsis GAPC 1 and cysteine variants (C153S and C149S mutants) were transformed in E. coli BL21DE3 (Invitrogen). A starter culture (LB containing $50 \mu \mathrm{g} / \mathrm{ml}$ kanamycin) was grown ovemight at $37^{\circ} \mathrm{C}$. The volume was expanded to 1 liter, and the culture was incubated until it reached an $\mathrm{OD}_{600}$ of $\sim 0.5$. Expression was induced by adding IPTG at the final concentration of 0.1 $\mathrm{mM}$. After $16-18 \mathrm{~h}$ of incubation at $25^{\circ} \mathrm{C}$, bacteria were pelleted by centrifugation $(5,000$ g, $15 \mathrm{~min}, 4^{\circ} \mathrm{C}$ ), resuspended in buffer $\mathrm{A}$ ( $30 \mathrm{mM}$ Tris-HCl, pH 7.9, $100 \mathrm{mM} \mathrm{NaCl}$ and $5 \mathrm{mM}$ imidazole) and lysed by sonication as described previously (Bedhomme et al., 2012 Biochem J). Lysates were centrifuged $\left(30,000 \mathrm{~g}, 30 \mathrm{~min}, 4^{\circ} \mathrm{C}\right)$ and supernatants passed through a $0.22 \mu \mathrm{m}$ filter. Filtered supematants were passed over a $\mathrm{Ni}^{2+}$ His-Trap chelating resin pre-equilibrated with buffer $A$. His-tagged proteins were then eluted according to the manufacturer's instructions. Eluted fractions were analyzed by SDS-PAGE to assess purity grade. Selected fractions were pooled and desalted against buffer B (50 mM potassium phosphate, pH 7.5) using PD-10 columns (GE Healthcare). Desalted proteins were stored in buffer $\mathrm{B}$ at $-20{ }^{\circ} \mathrm{C}$. The concentration of purified proteins was determined spectrophotometric ally using a molar extinc tion coeffic ient at $280 \mathrm{~nm}$ of $40,910 \mathrm{M}^{-1} \mathrm{~cm}^{-1}$.

GAPDH activity assay. The activity of GAPDH was monitored as described previously (Zaffagnini et al., 2007 FEBS ) ). Briefly, assa ys c onta ined 20-50 nM GAPDH (WT and cysteine variants), $5 \mathrm{mM} \mathrm{MgCl}$, $3 \mathrm{mM}$ 3-phosphoglycerate, 5 units $\mathrm{ml}^{-1}$ of baker's yeast PG K, $2 \mathrm{mM}$ ATP, $0.2 \mathrm{mM}$ NADH and $1 \mathrm{mM}$ EDTA in $50 \mathrm{mM}$ Tris-HCl (pH 7.5). Initial rates were determined at $25^{\circ} \mathrm{C}$ by measuring the decrease of absorbance at $340 \mathrm{~nm}$ (NADH oxidation) during the first 1-2 min using a Cary60 UV/Vis spectrophotometer (Agilent Technologies). 
Oxidation treatments of recombinant AtGAPC1. Recombinant proteins were incubated with $10 \mathrm{mM}$ dithiothreitol (DTT) for $30 \mathrm{~min}$ and then desalted using NAP-5 columns (GE Healthcare) pre-equilibrated with $50 \mathrm{mM}$ Tris-HCI, $1 \mathrm{mM}$ EDTA, pH 7.5 (buffer C). For oxidation experiments, pre-reduced samples $(5 \mu \mathrm{M})$ were treated with $0.125 \mathrm{mM} \mathrm{H}_{2} \mathrm{O}_{2}$ alone or supplemented with $0.625 \mathrm{mM} \mathrm{GSH}$. All treatments were caried out at $25{ }^{\circ} \mathrm{C}$ in buffer $\mathrm{C}$ supplemented with $0.14 \mathrm{mM} \mathrm{NAD+}$. At the indicated times, an aliquot was withdrawn to assay residual GAPDH activity. Activity data expressed as a percentage of maximal activity were plotted versus time. Interpolation curves were generated by nonlinear regression using CoStat (CoHort Software). For recovery assays, 20 mM DTT were added at different time points to AtG APC1 treated with $\mathrm{H}_{2} \mathrm{O}_{2}$ alone or supplemented with GSH. After 20 min incubation, a liquots were withdrawn for the a ssay of GAPDH activity.

Aggregation kinetics measured by turbidity. Kinetics of AtGAPC1 aggregation were assessed by measuring the increase of turbidity at $405 \mathrm{~nm}$. AtGAPC 1 samples (WT and Cys variants) were incubated at $25{ }^{\circ} \mathrm{C}$ with or without $0.125 \mathrm{mM} \mathrm{H}_{2} \mathrm{O}_{2}$ alone or supplemented with $0.625 \mathrm{mM} \mathrm{GSH}$ in a low-protein-binding 96-well plate. All treatments were performed

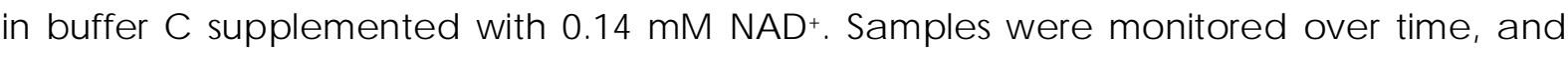
turbidity at $405 \mathrm{~nm}$ was measured using a plate reader (Victor3 Multilabeling Counter; Perkin Elmer).

\section{Dynamic light scattering}

Size distribution of the species present in samples were obtained from measurements of AtGAPC 1 (WT and Cys variants) incubated with or without $\mathrm{H}_{2} \mathrm{O}_{2}$ alone or supplemented with GSH in buffer C plus $0.14 \mathrm{mM} \mathrm{NAD}^{+}$at $25^{\circ} \mathrm{C}$. The data were obtained using Zetasizer Nano (Malvem) cuvettes and thirty spectra were acquired for each DLS analysis, averaged and used to detemine the hydrodynamic diameter and polydispersity using the average autocorrelation function.

ANS fluorescence assay. AtGAPC 1 samples were incubated with or without $\mathrm{H}_{2} \mathrm{O}_{2}$ supplemented with GSH as described above. After 90 min incubation, aliquots were withdrawn and treated with $5 \mu \mathrm{M}$ 1-anilinonaphthalene-8-sulfonic acid (ANS). Emission fluorescence spectra were acquired using a Cary Eclypse spectrofluorometer (Varian) in a 
$400-600 \mathrm{~nm}$ range at a $50 \mathrm{~nm} \mathrm{m^{-1 }}$ scan rate with an excitation wavelength of $380 \mathrm{~nm}$ and $5 \mathrm{~nm}$ slit width.

Thioflavin-T fluorescence assay. AtGAPCl samples were incubated with or without $\mathrm{H}_{2} \mathrm{O}_{2}$ supplemented with GSH as described above. After 90 min incubation, aliquots were withdrawn and treated with $25 \mu \mathrm{M}$ thioflavin-T (Th-T). Emission fluorescence spectra were recorded after 2 min equilibration using a Cary Eclypse spectrofluorometer (Varian) in a 450-650 $\mathrm{nm}$ range at a $50 \mathrm{~nm} \mathrm{m^{-1 }}$ scan rate with an excitation wavelength of $445 \mathrm{~nm}$ and $5 \mathrm{~nm}$ slit width.

\section{Crystallization and data collection}

Crystals of NAD+-AtGAPC1 were grown as previously reported in (Zaffagnini et al. 2016 ARS). Native crystals were soaked in the reservoir solution composed by $3.0 \mathrm{M}\left(\mathrm{NH}_{4}\right)_{2} \mathrm{SO}_{4}$

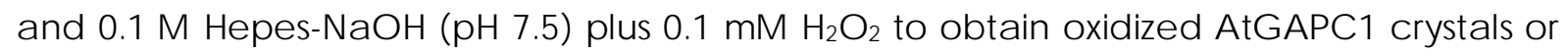
plus $0.1 \mathrm{mM} \mathrm{H} \mathrm{H}_{2}$ and $1 \mathrm{mM} \mathrm{GSH}$ to obtain glutathionylated AtGAPC1 crystals. The $\mathrm{H}_{2} \mathrm{O}_{2} / \mathrm{GSH}$ molar ratio used in soaking experiments was doubled with respect to biochemical assays as the protein molecules were constrained in a crystalline lattice. Preliminary tests showed that the AtGAPC1 crystals were stable in the soaking solutions. The soaking was performed for 1 month then the crystals were fished and briefly soaked in a cryo solution containing $3.2 \mathrm{M}\left(\mathrm{NH}_{4}\right)_{2} \mathrm{SO}_{4}$ and $20 \% \mathrm{v} / \mathrm{v}$ glycerol.

Diffraction data were collected using the synchrotron radiation of Elettra (Trieste, Italy) XRDlbeam line, at $100 \mathrm{~K}$ with a wavelength of $1.26 \AA$, an oscillation angle of $1^{\circ}$ and a sa mple-to-detector (Pila tus 2M) distance of $250 \mathrm{~mm}$ for oxidized AtGAPC 1 and $260 \mathrm{~mm}$ for gluta thionylated AtG APC 1 crystals. The images were indexed with XDS (Kabsch 2010, Acta Cryst. D.) and scaled with SCALA (Evans 2006, Acta Cryst. D) from the CCP4 package. The unit cell parameters and the data collection statistics a re reported in Table S1.

Table S1: Data collection and refinement statistics

\begin{tabular}{lll}
\hline & Data collection & \\
\hline Resolution range $(\AA) *$ & $\mathrm{H}_{2} \mathrm{O}_{2}$-0xidized AtGapC1 & G SH-AtGapC1 \\
Space group & $47.79-3.00(3.16-3.00)$ & $47.66-2.99(3.16-2.99)$ \\
Unit cell a, b, c $(\AA)$ & $\mathrm{P} 6{ }_{1} 22$ & $\mathrm{P} 6122$ \\
Total reflections* & $77.68,77.68,407.35$ & $77.37,77.37,406.81$ \\
\hline
\end{tabular}




\begin{tabular}{|c|c|c|}
\hline Unique reflections* & $15798(2164)$ & $15692(2155)$ \\
\hline Rmerge* & $0.112(0.453)$ & $0.088(0.303)$ \\
\hline Rpim* & $0.043(0.168)$ & 0.021 \\
\hline$/ / \square(/)^{*}$ & $13.5(4.1)$ & $25.1(9.1)$ \\
\hline Completness* & $99.8(98.6)$ & $99.7(98.0)$ \\
\hline \multirow[t]{2}{*}{ Multip lic ity* } & $7.8(8.1)$ & $18.7(19.4)$ \\
\hline & Refinement & \\
\hline Resolution range $(\AA)$ & $47.79-3.00$ & $47.66-2.99$ \\
\hline Reflection used & 15739 & 15571 \\
\hline$R / R_{\text {free }}$ & $0.228 / 0.292$ & $0.249 / 0.303$ \\
\hline msd bonds/angles $\left(\AA,{ }^{\circ}\right)$ & $0.004 / 0.932$ & $0.010 / 1.402$ \\
\hline \multicolumn{3}{|l|}{$N^{\circ}$ atoms } \\
\hline Protein & 5140 & 5126 \\
\hline Waters & 33 & 35 \\
\hline Hetero & 123 & 163 \\
\hline \multicolumn{3}{|l|}{$B$ value $\left(\AA^{2}\right)$} \\
\hline Mean & 72.9 & 73.1 \\
\hline Protein & 73.3 & 73.6 \\
\hline Waters & 36.7 & 38.2 \\
\hline Hetero & 66.5 & 64.4 \\
\hline \multicolumn{3}{|l|}{ Ramachandran plot (\%) } \\
\hline Most favored & 87.2 & 94.3 \\
\hline Allowed & 10.4 & 3.9 \\
\hline Disallowed & 2.4 & 1.8 \\
\hline
\end{tabular}

*Values in parenthesis refers to the last resolution shell

\section{Structure Solution and Refinement}

Since the unit cell parameters were not affected by the soaking, the AtGAPC 1 structure (PDB code 4ZOH, Zaffagnini et al., 2016 ARS) was directly used in the refinement against the experimental data of the oxidized and glutathionylated AtGAPC 1 crystals. After an energy minimization and B factor refinement with CNS1.3 (Brünger et al., 1998 Acta Cryst. D) selecting $5 \%$ of reflections for Rfree calculation, the starting $R$ and Rfree were 0.289 and 0.361 for oxidized AtGACP1, and 0.237 and 0.287 for glutathionylated AtGAPC1. The calculated Fo-Fc electron density map clearly showed for both cases large positive electron densities in correspondence and near the thiol group of residue Cys149. In the case of oxidized AtGAPC1 a sulphinic group was built, while for glutathionylated AtGAPC 1 a glutathione molecule forming a mixed disulphide bond with Cys149, was modeled into the densities. The manual rebuilding was performed with Coot (Emsley and Cowtan 2004 
Acta Cryst. D). In the final stages of refinement performed with REFMAC5.5 (Murshudov et al., 2011 Acta Cryst. D) water molecules were automatically added, and after a visual inspection they were conserved in the model only if contoured at $1.0 \sigma$ on the $\left(2 F_{0}-F_{c}\right)$ map and if they fell into an appropriate hydrogen bonding environment. Stereo-chemic al quality of the models was checked with PROCHECK (Laskowski et al., 1993) and protein superimpositions were performed by LSQKAB (Vagin and Teplyakov 2010 Acta Cryst. D) from CCP4 package. Refinement statistic s a re reported in Table S1.

\section{Fourier transform infrared (FIR) analysis}

FIR absorption measurements were performed at room temperature with a J asco Fourier transform 6100 spectrometer, equipped with a DLATGS detector. The spectra were acquired with $2 \mathrm{~cm}^{-1}$ resolution in the whole mid-IR range $\left(7000-1000 \mathrm{~cm}^{-1}\right)$, using a standard high-intensity ceramic source and a $\mathrm{Ge} / \mathrm{KBr}$ beam splitter. Ten $\mu$ l of AtGAPC 1 solution sample at $10 \mathrm{mg} \mathrm{ml}^{-1}$ in $\mathrm{D}_{2} \mathrm{O}$ was deposited between two $\mathrm{CaF}_{2}$ windows, separated by a $50 \mu \mathrm{m}$ teflon spacer, and mounted into a J asco MagCEШ sample holder. All spectra were obtained by averaging $10^{3}$ interferograms.

$\mathrm{H}_{2} \mathrm{O}$ to $\mathrm{D}_{2} \mathrm{O}$ substitution was performed in the samples to avoid the overlapping of the spectral contribution due to the $\mathrm{H}_{2} \mathrm{O}$ bending mode, at around $1640 \mathrm{~cm}^{-1}$ (Marechal, 2011 J. Mol. Struct.), with the amide I band of the AtGAPC 1, centered at approximately 1650 $\mathrm{cm}^{-1}$. Starting from $1 \mathrm{ml}$ containing native AtGAPC1 $\left(0.2 \mathrm{mg} \mathrm{ml}^{-1}\right)$ in buffer C supplemented with $0.14 \mathrm{mM} \mathrm{NAD}{ }^{+}, \mathrm{D}_{2} \mathrm{O}$ substitution was achieved by progressive dilution of $\mathrm{H}_{2} \mathrm{O}$ in $\mathrm{D}_{2} \mathrm{O}$ through several concentration-dilution cycles, by using Centric on Amic on filters with a cut-off of $10 \mathrm{kDa}$. The procedure was applied up to a final, nominal dilution corresponding to $1 \mathrm{H}_{2} \mathrm{O}: 7 \times 10^{4} \mathrm{D}_{2} \mathrm{O}$. The efficacy of replacement was tested by comparing the FT-IR spectrum of the flow-through solution with that of pure $\mathrm{D}_{2} \mathrm{O}$; the comparison clearly showed that in the spectral interval of the amide I $\left(1750-1570 \mathrm{~cm}^{-1}\right)$ the two spectra essentially coincided (not shown). The $\mathrm{D}_{2} \mathrm{O}$-substituted AtGAPC1 solution was finally concentrated up to $10 \mathrm{mg} \mathrm{ml}^{-1}$. Spectral analysis of the amide I bands was performed after subtracting the spectrum of the buffer solution (i.e. the final flow-through of the $\mathrm{D}_{2} \mathrm{O}$-substitution procedure), and by approximating the residual background with a cubic spline function with the OriginPro 9.1 software (OriginLab Corporation, Northampton MA, USA). Second and fourth derivative spectra in the amide I' region were calculated using the $i$-signal program (version 2.72) included in the SPECTRUM suite (SPECTRUM: A Signal Processing Toolkit, Version 1.1, 1990) written in MATLAB language. A Savitsky-Golay 
algorithm was employed to smooth the signals and calculate the derivatives. The smooth width was chosen by evaluating step-by-step the impact of increasing the smoothing on the calculation of the derivative spectrum, with the aim of optimizing the signal to noise ratio without loosening spectral information. The decomposition of the amide I into Gaussian components was performed by using a locally developed least-squares minimization routine (Malferrari et al., 2015 J Phys Chem B), based on a modified grid search algorithm (Bevington, 1969). Confidence intervals for the best-fit parameters were evaluated numerically, as detailed in (Francia et al., 2009 J Phys Chem B). The peak wavenumbers of the Gaussian components were fixed to values inferred from the second and fourth derivative analysis, while the areas and the widths were treated as free parameters. Since both the second and the fourth derivative spectra can in principle exhibit artefactual peaks (i.e. not reflecting genuine components of the original spectrum) (Butler, 1970), we considered as reliable peaks only those which were present at the same wavenumber (within our spectral resolution, $2 \mathrm{~cm}^{-1}$ ) both in the second and in the fourth derivative spectra. This criterion resulted for the control in peaks fixed at 1683, 1669, 1654, 1637 and $1628 \mathrm{~cm}^{-1}$.

The aggregated AtGAPC 1 was prepared by incubating the protein sample with $\mathrm{H}_{2} \mathrm{O}_{2}$ and GSH as described earlier. After 90 min incubation, the sample solution was centrifuged at $10,000 \mathrm{~g}$ for $15 \mathrm{~min}$ and the resulting pellet was resuspended with an adequate $\mathrm{D}_{2} \mathrm{O}$ volume to attain $10 \mathrm{mg} \mathrm{ml}^{-1}$ protein concentration. FT-IR analysis was carred out as described before and six Gaussian components with peak wavenumber fixed at 1682 , 1660, 1652, 1644, 1636 and $1624 \mathrm{~cm}^{-1}$ were used.

\section{Electron microscopy}

AtGAPC 1 samples were incubated with $\mathrm{H}_{2} \mathrm{O}_{2}$ supplemented with $\mathrm{GSH}$ as described above, then deposited onto carbon-coated copper mesh grids, and negatively stained with $2 \%(w / v)$ uranyl acetate. The excess stain was wicked away, and the sample grids were allowed to a ir dry. The samples were viewed with an FEI Tecnai 12 BioTwin $85 \mathrm{kV}$ transmission electron mic rosc ope (TEM), and digital images were taken with an Advanced Microscopy Techniques camera. The scanning electron microscope (SEM) observations were conducted using a Hitachi S-4000. The samples were deposited on a mica layer and gold coated $(2 \mathrm{~nm})$ prior the observations. 


\section{MALDI-TOF Mass spectrometry}

AtGAPC 1 samples (WT and C 1535 mutant; $5 \mu \mathrm{M}$ ) were incubated at $25^{\circ} \mathrm{C}$ with $0.125 \mathrm{mM}$ $\mathrm{H}_{2} \mathrm{O}_{2}$ supplemented with $0.625 \mathrm{mM} \mathrm{GSH}$ in buffer $\mathrm{C}$ containing $0.14 \mathrm{mM}$ NAD+. At different time points, aliquots were withdrawn for MADI-TOF mass spectrometry analysis using a Performance Axima MALDI-TOF mass spectrometer (Shimadzu-Kratos, Manchester, United Kingdom) equipped with a $337 \mathrm{~nm}$ nitrogen laser. For mass determination of AtGAPC 1 samples, spectra were acquired as described previously (Berger et al., 2016, Plant Physiol) with a pulse-extraction fixed at 60,000 . For each time point, $4 \mu \mathrm{l}$ of the reaction mixture were mixed with $2 \mu \mathrm{l}$ of $1 \%$ trifluoroacetic acid (TFA) and then kept on ice to quench the reaction. To assess the effect of a reducing treatment, $4 \mu \mathrm{l}$ of the reaction mixture was incubated for $15 \mathrm{~min}$ at $25^{\circ} \mathrm{C}$ with $2 \mathrm{mM}$ DTT in $50 \mathrm{mM}$ ammonium bic arbonate before being processed as described above. Immediately after acidification, $1 \mu$ of sample and $3 \mu \mathrm{l}$ of a saturated solution of sinapinic acid in $30 \%$ acetonitrile containing $0.3 \%$ TFA were mixed together and $3 \mu \mathrm{l}$ were deposited onto the sample plates for MS analysis. Spectra were acquired and processed as followed using the Launchpad software (ShimadzuKratos, version 2.8). Briefly, no baseline subtraction was perfomed but raw data were smoothed using an algorithm averaging MS data within a smoothing filter width of 40 time channels. Protein peaks were delimited manually and the software for both mass determination and peak area quantific ation used these limits. Peak areas were expressed as a percentage of the sum of all areas corresponding to AtGAPC 1 proteoforms.

For peptide analysis, the aggregated AtGAPC1 was prepared by incubating the protein sample with $\mathrm{H}_{2} \mathrm{O}_{2}$ and $\mathrm{GSH}$ as described above in a $500 \mu$ reaction mixture. After 90 min incubation, the sample was centrifuged for $5 \mathrm{~min}\left(10,000 \mathrm{~g}, 20^{\circ} \mathrm{C}\right)$ and the resulting pellet was solubilized in $11 \mu \mathrm{l}$ of $50 \mathrm{mM}$ ammonium bicarbonate containing $5 \mathrm{mM}$ iodoacetamide and $\mathbf{0 . 0 1 \%}$ of MS-compatible ProteaseMax detergent (Promega). After resolubilization, $5 \mu \mathrm{l}$ were mixed with $1 \mu$ of a mixture of Trypsin/Lysine $C$ endoproteases (Promega) prepared at $0.1 \mu \mathrm{g} \mathrm{\mu l}^{-1}$ in $1 \mathrm{mM} \mathrm{HCl}$ and leaved at $30^{\circ} \mathrm{C}$ for $20 \mathrm{~min}$. After incubation, $5 \mu$ of $50 \mathrm{mM}$ ammonium bicarbonate were added and digestion was completed at $30^{\circ} \mathrm{C}$. To assess the effect of reducing agents, one-half of the digestion mixture was subjected to DTT reduction. Tryptic digests were then acidified as described above and prepared for MADI-TOF mass spectrometry as described in (Morisse et al., 2014 J BC). Peptide mass fingerprints were acquired in the positive reflectron ion mode after extemal calibration and processed with the same software as described above. Raw MS spectra were smoothed with a Gaussian algorithm using a smoothing filter width of 2 
time channels. Baselines of MS spectra were also corrected using a ba seline filter of 6 time channels. Monoisotopic peak recognition of peptides present in peptide mass fingerprints was done using the Poisson peptide algorithm and monoisotopic peaks were considered if they had at least 2 additional isotopes and showed with them a maximum intensity variation of $80 \%$.

\section{Molec ular dynamics}

We set up simulation systems for AtGAPC1 in complex with NAD+ in both reduced and glutathionylated form using 3 different treatments of the NAD+ cofactor leading to 6 independent simulations. The first simula tion set was run without any constra ints. At the end of the production, for both reduced and glutathionylated forms, 3 out of 4 NAD+ left their binding sites. Although such partial occupation is not unexpected, we wanted to investigate here also the scenario of full occupation of all sites. For this purpose, we introduced distance restraints between $\mathrm{NAD}^{+}$and protein $\mathrm{C}_{a}$ atoms in the two other simulation sets. In simulation set 2 , distance restra ints were applied between the two NAD+ ribose O4' atoms and the closest Gly11 and Ile13 $\mathrm{C}_{a}$ atoms with a force constant of $500 \mathrm{~kJ} \mathrm{~mol}^{-1} \mathrm{~nm}^{-2}$. In simulation set 3 the same two distance restraints were applied with a higherforce constant of $2000 \mathrm{~kJ} \mathrm{~mol}^{-1} \mathrm{~nm}^{-2}$ and two additional restra ints involving the NAD ${ }^{+}$ adenine $\mathrm{N3}^{\prime}$ and $\mathrm{N} 315 \mathrm{C}_{a}$ atoms, and the NAD+ nic otinamide C4' and D34 $\mathrm{C}_{a}$ atoms.

In all simulations, summarized in Table S2, Protein Data Bank ID 4Z0H was used as starting structure for the NAD+-GAPC1 complex in reduced form, whereas the crystal structure presented in this work was used for the glutathionylated form. Default protonation at $\mathrm{pH}$ 7.0 wasused for all residues with the exception of the catalytic residues; His176 was doubly protonated and Cys149 was deprotonated for the reduced form or linked to the glutathione molecule in the glutathionylated form. Both forms were solvated in a dodecahedron box using periodic boundary conditions and a $\sim 1.5 \mathrm{~nm}$ water shell. In four of the six simulation systems (numbered from 1 to 4 in Table S2) only a minimal number of counter ions was inserted to neutralize the charge of the protein (12 sodium ions). In the two remaining systems, $\sim 150 \mathrm{mM}$ of salt $\left(\mathrm{Na}^{+} \mathrm{Cl}^{-}\right)$were included.

Molecular dynamics simulations were caried out using the CHARMM 36 force field for protein and the TIP3P model ${ }^{4}$ for water. The Gromacs 4.5 software was used to run the simulations using the virtual interaction sites approach, allowing a 5fs integration time step. Neighbor searching was performed every 5 steps. All bonds were constrained using the 
LINCS a lgorithm. The PME a lgorithm was used for electrostatic interactions with a cut-off of $1 \mathrm{~nm}$. A single cut-off of $1 \mathrm{~nm}$ was used for Van der Waals interactions. Two independent baths for protein and solvent were coupled to a temperature of $310 \mathrm{~K}$ using the Bussy velocity rescaling themostat with a time constant of $\mathrm{T}=0.1 \mathrm{ps}$. Pressure coupling was scaled isotropically using the Berendsen weak barostat to a reference pressure of $1 \mathrm{bar}, \mathrm{T}$ $=5.0$ ps and compressibility of $4.510^{-5} \mathrm{bar}^{-1}$.

All systems were minimized for 10,000 steps with a steepest desc ent a lgorithm, equilibra ted for $10 \mathrm{~ns}$, using position restraints of $1000 \mathrm{~kJ} \mathrm{~mol}^{-1} \mathrm{~nm}^{-2}$ on heavy atoms with the crystal structure as a reference, followed by an equilibration of 20 ns using position restraints of $1000 \mathrm{~kJ} \mathrm{~mol}^{-1} \mathrm{~nm}^{-2}$ on $\mathrm{C}_{a}$ atoms, and finally $20 \mathrm{~ns}$ using position restraints of $10 \mathrm{~kJ} \mathrm{~mol}^{-1}$ $\mathrm{nm}^{-2}$ on $\mathrm{C}_{a}$ atoms. Production runs were computed for $1 \mu$ s without a ny position restraints.

Table S2: Simulation systems overview

\begin{tabular}{|c|c|c|c|c|c|c|c|}
\hline $\begin{array}{c}\text { Simulation } \\
\text { Set }\end{array}$ & \# & Acronym & Functional form & $\begin{array}{l}\text { [lon] } \\
(\mathrm{mM})\end{array}$ & $\begin{array}{c}\text { Constraint force on } \\
\text { NAD }^{+} \\
\text {(kJ .mol-1.nm-2) }\end{array}$ & $\begin{array}{c}\text { Composition } \\
\text { (water/ } \mathrm{Na}^{+} / \mathrm{Cl} \text { ) }\end{array}$ & $\begin{array}{c}\text { Atom } \\
\text { number }\end{array}$ \\
\hline \multirow[t]{2}{*}{1} & 1 & Red & reduced & $\sim 0$ & 0 & $27033 / 12 / 0$ & 104075 \\
\hline & 2 & Glut & glutathionylated & $\sim 0$ & 0 & 26741 / 12 / 0 & 103051 \\
\hline \multirow[t]{2}{*}{2} & 3 & Red_low_constr & reduced & $\sim 0$ & 500 & 27033 / 12 / 0 & 104075 \\
\hline & 4 & Glut_low_constr & glutathionylated & $\sim 0$ & 500 & $26741 / 12$ / 0 & 103051 \\
\hline \multirow[t]{2}{*}{3} & 5 & Red_high_constr & reduced & $\sim 150$ & 2000 & 26889 / 84 / 72 & 103787 \\
\hline & 6 & Glut_high_constr & glutathionylated & $\sim 150$ & 2000 & 26597 / 84 / 72 & 102673 \\
\hline
\end{tabular}

\section{Accession Number}

The atomic coordinates and structure factors of the oxidized AtGAPC1 (AtG APC1-SO ${ }_{2} \mathrm{H}$ ) and glutathionylated AtGAPC1 (AtGAPC 1-SSG) have been deposited in the Protein Data Bank under accession codes PDB XXXX and PDB XXX, respec tively. 


\section{Legends to Supplementary Figures}

\section{Figure S1.}

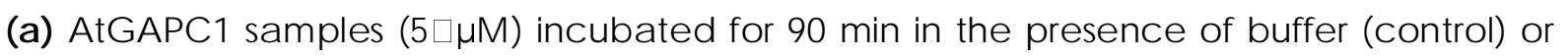
$0.125 \mathrm{mM} \mathrm{H}_{2} \mathrm{O}_{2}$ supplemented with $0.625 \mathrm{mM} \mathrm{GSH}$ were loaded on a $4-20 \%$ SDS-PAGE under reducing (+) and non-reducing conditions (-). (b) Fluorescence emission spectrum of thioflavin T (ThT) with untreated (black line) or treated AtGAPC1 (red line). The treatment consisted of 90 min incubation of AtGAPC1 in the presence of buffer or $\mathrm{H}_{2} \mathrm{O}_{2}$ supplemented with GSH. Binding of amyloid-specific ThT to the aggregated AtGAPC1 resulted in a 2-fold increase of fluorescence emission at $482 \mathrm{~nm}$. (c) Fluoresc ence emission spectrum of 1-anilinonaphthalene-8-sulfonic acid (ANS) with untreated (black line) or treated AtGAPC 1 (red line). The treatment consisted of 90 min incubation of AtG APC 1 in the presence of buffer or $\mathrm{H}_{2} \mathrm{O}_{2}$ supplemented with $\mathrm{GSH}$. Binding of ANS to the aggregated AtGAPC1 resulted in a red-shift of the peak and a concomitant $\sim 10$-fold increase of maximal fluorescence emission.

\section{Figure S2. FIR analysis of native and aggregated AtGAPC1}

FIIR spectra of the amide I region of native (a) and aggregated (c) AtGAPC1. The individual Gaussian components, corresponding to the different secondary structure elements, are plotted using the same colour code of Figure 1 (panel e and $f$ ), and the resulting fit is shown as a red curve (see "Online Methods" for details of the analysis). (b) Difference FIR spectra between native and aggregated AtG APC 1.

\section{Figure S3. Effect of S-glutathionylation on AtGAPC1}

(a) Time-c ourse DLS a nalysis of AtG APC 1 trea ted with $\mathrm{H}_{2} \mathrm{O}_{2}$ and GSH. The protein diameter (closed circles) was monitored as described in Figure $2 \mathrm{c}$ and plotted versus time (0-30 min). Data represent mean \pm s.d., $n=3$ experiments with technic al duplicates. (b) MADITOF spectra of AtGAPC 1 treated with $\mathrm{H}_{2} \mathrm{O}_{2}$ and $\mathrm{GSH}$. At indicated time points, AtGAPC 1 samples were withdrawn, mixed in a ratio 2:1 (v/v) with sinapinic acid and analysed by MALDI-TOF MS to assess the redox state of the protein: glutathionylated (-SSG, $\sim 305 \mathrm{Da}$ shifted) versus native/oxidized (-Sox, not shifted). The peak highlighted by an asterisk 
corresponds to the protein-matrix adduct. The spectra are representative of three biological replicates. (c) Distance between the thiol groups of the catalytic Cys149 and the Cys153 in AtGAPC1 structure (PDB ID 4ZOH; Zaffagnini et al., 2016 ARS). The a-helix containing the two cysteine residues displayed as stic ks is highlighted in yellow.

\section{Figure S4. Treatment with $\mathrm{H}_{2} \mathrm{O}_{2}$ does alter AtGAPC1 withoutaffec ting protein folding}

(a) Inactivation kinetics of AtGAPC 1 in the presence of $\mathrm{H}_{2} \mathrm{O}_{2}$. Treatment of AtG APC 1 with $\mathrm{H}_{2} \mathrm{O}_{2}$ causes a rapid inactivation with a complete loss of protein activity after 10 min. Data represent mean \pm s.d., $n=3$ experiments with technical duplic ates. (b) Time-course DTTdependent reactivity of inactivated AtGAPC 1 . At different time points, AtG APC 1 samples treated with $\mathrm{H}_{2} \mathrm{O}_{2}$ were further incubated with DTT to assess the inactivation reversibility, which was found null at each incubation times. Data represent mean \pm s.d., $n=3$ experiments with technical duplicates. (c) Size exclusion chromatography of native and $\mathrm{H}_{2} \mathrm{O}_{2}$-treated AtG APC 1 . The protein maintained its tetrameric structure under both control (dotted line) and oxidizing (continuous line) conditions. Molecular masses of standard proteins are indicated as closed circles. (d) Representation of the crystal structure of oxidized AtGAPC1. The dimer (chains are named $O$ and $Q$ ) composing the asymmetric unit is shown ascartoon and surface while the symmetry-related subunits completing the tetramer, are shown as a surface. The oxidized catalytic cysteines (sulphinic group) and the cofactor (NAD) are shown as sticks. A magnification of the catalytic cysteines with their environment and the $2 F_{o}-F_{c}$ electron density map (contoured at $1.5 \sigma$ ), is also reported.

\section{Figure S5. Position and accessibility of methionine residues and Cys153}

The position of the seven methionine residues found in the sequence of AtGAPC 1, and Cys153 is shown. The residues are represented as sticks. The values of calculated accessible surface area $(A S A)$ are: $\operatorname{Met} 40(O / Q)=1.8 / 2.0 \AA^{2} ;$ Met43(O/Q) $=10.8 / 10.6 \AA^{2}$; $\operatorname{Met127}(\mathrm{O} / \mathrm{Q})=13.0 / 13.2 \AA^{2} ; \operatorname{Met172}(\mathrm{O} / \mathrm{Q})=0.1 / 0.2 \AA^{2} ; \operatorname{Met190}(\mathrm{O} / \mathrm{Q})=83.1 / 83.0 \AA^{2}$; Met228(O/Q) =5.6/5.9 $\AA^{2} ; \operatorname{Met328}(\mathrm{O} / \mathrm{Q})=10.2 / 10.3 \AA^{2} ; \mathrm{Cys} 153(\mathrm{O} / \mathrm{Q})=0.0 / 0.0 \AA^{2}$.

\section{Figure S6. Molec ular dynamics simulations on glutathionylated AtGAPC1}


The main conformational clusters of the glutathione obtained from multiple molecular dynamics (MD) simulations (1 $\mu s$ ) starting from the crystal structure of glutathionylated AtG APC 1, a re shown. The bottom graphs assign each simulation snapshot to one of the six conformations using a color code. Clusters confimed the high mobility of bound GSH. Cluster 2 is the closest to the starting crystal structure. The glycine residue $\left(G_{G \pi}\right)$ of gluta thione is more mobile than the gluta mate residue $\left(E_{G T}\right)$ that forms several interactions with protein residues in most clusters (cut-off distance $3.5 \AA$ ). The structural clustering of glutathione conformations was achieved after computing the RMSD matrix between all pairs of glutathione coord inates, using the gromos algorithm (Angew. Chem. Int. Ed. 1999, 38 , pp 236-240) with a cutoff of $2.5 \AA$, for each of the four chains of the three simulations of AtGAPC 1 in the glutathionylated form.

\section{Figure S7. Effect of S-glutathionylation on the C153S mutant}

(a) Inactivation kinetic s of the $\mathrm{C} 153 \mathrm{~S}$ mutant in the presence of $\mathrm{H}_{2} \mathrm{O}_{2}$ and $\mathrm{GSH}$. Treatment of $\mathrm{C} 153 \mathrm{~S}$ with $\mathrm{H}_{2} \mathrm{O}_{2}$ and $\mathrm{GSH}$ causes a rapid inactivation with a complete loss of protein activity after 15 min incubation. Inset, inactivation kinetics of AtGAPC1 WT and C153S revealed an identical response of both proteins to the inactivation treatment. Data represent mean \pm s.d., $n=3$ experiments with technical duplic ates. (b) Time-course DTTdependent reactivity of inactivated C153S. At different time points, C153S samples treated with $\mathrm{H}_{2} \mathrm{O}_{2}$ and $\mathrm{GSH}$ were further incubated with DTT to assess the inactivation reversibility, which wasfound to be stric tly dependent on inc ubation times. Data represent mean \pm s.d., $n=3$ experiments with technic al duplic ates. (c) MADI-TOF spectra of C153S mutant treated with $\mathrm{H}_{2} \mathrm{O}_{2}$ and $\mathrm{GSH}$. At indicated time points, C153S samples were withdrawn, mixed in a ratio 2:1 (v/v) with sinapinic acid and analysed by MADI-TOF to assess the redox state of the protein: glutathionylated (-SSG, 305 Da shifted) versus native/oxidized (-Sox, not shifted). The peak highlighted by an asterisk corresponds to the protein-matrix adduct. The spectra a re representative of three biological replicates. 


\section{REFRENCES}

1. Dobson, C.M. Protein folding and misfolding. Nature 426, 884-90 (2003).

2. $\quad$ Tyedmers, J ., Mogk, A. \& Bukau, B. Cellular strategies for controlling protein aggregation. Nat Rev Mol Cell Biol 11, 777-88 (2010).

3. Vendruscolo, M. Proteome folding and aggregation. Curr Opin Struct Biol 22, 138-43 (2012).

4. Vetri, V. \& Fodera, V. The route to protein aggregate superstruc tures: Partic ulates and a mylo id-like spherulites. FEBS Lett 589, 2448-63 (2015).

5. Chiti, F. \& Dobson, C.M. Protein Misfolding, Amyloid Fomation, and Human Disease: A Summary of Progress Over the Last Decade. Annu Rev Biochem 86, 27-68 (2017).

6. Krebs, M.R., Devlin, G.L. \& Donald, A.M. Protein particulates: a nother generic form of protein aggregation? Biophys J 92, 1336-42 (2007).

7. Baldwin, A.J . et al. Meta stability of native proteins and the phenomenon of a myloid formation. J Am Chem Soc 133, 14160-3 (2011).

8. Hartl, F.U., Bracher, A. \& Hayer-Hartl, M. Molecular cha perones in protein folding and proteostasis. Nature 475, 324-32 (2011).

9. Finka, A., Mattoo, R.U. \& Goloubinoff, P. Expenimental M ilestones in the Disc overy of Molecular Chaperones as Polypeptide Unfolding Enzymes. Annu Rev Biochem 85, 715-42 (2016).

10. Mannini, B. \& Chiti, F. Cha perones as Suppressors of Protein M isfolded Oligomer Toxic ity. Front Mol Neurosci 10, 98 (2017).

11. Winkler, J . et al. Qua ntitative and spatio-temporal fea tures of protein aggregation in Escheric hia coli and consequences on protein quality control and cellular a geing. Embo J 29, 910-23 (2010).

12. Wallace, E.W. et al. Reversible, Specific, Active Aggregates of Endogenous Proteins Assemble upon Heat Stress. Cell 162, 1286-98 (2015).

13. Weids, A.J ., Ibstedt, S., Tamas, M.J . \& Grant, C.M. Distinct stress cond itions result in aggregation of proteins with simila r properties. Sci Rep 6, 24554 (2016).

14. David, D.C. et al. Widespread protein aggregation as an inherent part of aging in C. elegans. PLoS Biol 8, e1000450 (2010).

15. Walther, D.M. et al. Widespread Proteome Remodeling and Aggregation in Aging C. elegans. Cell 168, 944 (2017).

16. Nover, L., Scharf, K.D. \& Neumann, D. Formation of cytopla smic heat shock granules in toma to cell cultures and leaves. Mol Cell Biol 3, 1648-55 (1983).

17. Nakajima, Y. \& Suzuki, S. Environmental stresses induce misfolded protein aggregation in plant cells in a mic rotubule-dependent manner. Int J Mol Sci 14, 7771-83 (2013).

18. Wang, L., Colodner, K.J . \& Feany, M.B. Protein misfolding and oxidative stress promote glial-mediated neurodegeneration in an Alexander disease model. $J$ Neurosci 31, 2868-77 (2011).

19. Mulinacci, F., Poinier, E., Ca pelle, M.A., Gumy, R. \& Arvinte, T. Influence of methionine oxidation on the aggregation of recombinant human growth homone. Eur J Pharm Biopharm 85, 42-52 (2013).

20. Zhao, L., Buxbaum, J.N. \& Reixach, N. Age-related oxidative modific a tions of transthyretin modula te its a mylo idogenic ity. Biochemistry 52, 1913-26 (2013).

21. Samson, A.L. et al. Oxidation of an exposed methionine instigates the aggregation of glyceraldehyde-3-phosphate dehydrogena se. J Biol Chem 289, 26922-36 (2014).

22. Nakajima, H. et al. The active site cysteine of the proapoptotic protein glyc eraldehyde-3-phosphate dehydrogenase is essential in oxidative stress-induced aggregation and cell death. J Biol Chem 282, 26562-74 (2007). 
bioRxiv preprint first posted online Feb. 15, 2019; doi: http://dx.doi.org/10.1101/545921. The copyright holder for this preprint (which was not peer-reviewed) is the author/funder, who has granted bioRxiv a license to display the preprint in perpetuity. All rights reserved. No reuse allowed without permission.

23. Nakajima, H. et al. Glyceraldehyde-3-phosphate dehydrogenase aggregate formation partic ipates in oxida tive stress-induced cell death. J Biol Chem 284, 34331-41 (2009).

24. Carija, A., Nava rro, S., de Groot, N.S. \& Ventura, S. Protein a ggregation into insoluble deposits protec ts from oxidative stress. Redox Biol 12, 699-711 (2017).

25. Lindner, A.B., Madden, R., Demarez, A., Stewart, E.J . \& Ta ddei, F. Asymmetric segregation of protein aggregates is a ssociated with cellular aging and rejuvenation. Proc Natl Acad Sci U S A 105, 3076-81 (2008).

26. Glover, J.R. \& Lindquist, S. Hsp 104, Hsp 70, and Hsp40: a novel chaperone system that rescues previously a ggregated proteins. Cell 94, 73-82 (1998).

27. Ruan, L. et al. Cytosolic proteostasis through importing of misfolded proteins into mitoc hondria. Nature 543, 443-446 (2017).

28. Hara, T. et al. Suppression of basal autophagy in neural cells causes neuro degenera tive disease in mice. Nature 441, 885-9 (2006).

29. Komatsu, M. et al. Loss of a utophagy in the central nervous system causes neuro degeneration in mice. Nature 441, 880-4 (2006).

30. Torres-Bugeau, C.M. et al. Characterization of heparin-induced glyc eraldehyde-3phosphate dehydrogena se early amyloid-like oligomers and their implic ation in alpha-synuclein a ggregation. J Biol Chem 287, 2398-409 (2012).

31. Avila, C.L. et al. Struc tural characteriza tion of heparin-induced glyc era ld ehyde-3phosphate dehydrogenase protofibrils preventing alpha-synuclein oligomeric species toxic ity. J Biol Chem 289, 13838-50 (2014).

32. Henry, E., Fung, N., Liu, J ., Drakaka ki, G . \& Coaker, G. Beyond glyc olysis: G APDHs are multi-functional enzymes involved in regulation of ROS, autophagy, and plant immune responses. PLOS Genet 11, e1005199 (2015).

33. Itakura, M. et al. Glyc eraldehyde-3-phosphate Dehydrogenase Aggregates Accelera te Amyloid-beta Amyloidogenesis in Alzheimer Disease. J Biol Chem 290, 26072-87 (2015).

34. Muronetz, V.I., Ba rinova, K.V., Stroylova, Y.Y., Semenyuk, P.I. \& Sc hmalhausen, E.V. Glyc eraldehyde-3-phosphate dehydrogenase: Aggregation mechanisms and impact on amyloid neurodegenerative disea ses. Int J Biol Macromol 100, 55-66 (2017).

35. Zaffa gnini, M., Fermani, S., Costa, A., Lemaire, S.D. \& Trost, P. Plant cytopla smic GAPDH: redox post-translational modific ations and moonlighting properties. Front Plant Sci 4, 450 (2013).

36. Trost, P., Fermani, S., Calva resi, M.\& Zaffa gnini, M. Bioc hemic al basis of sulphenomics: how protein sulphenic acidsmay be stabilized by the protein mic roenvironment. Plant Cell Environ 40, 483-90 (2017).

37. Bedhomme, M. et al. G lutathionylation of cytosolic glyceraldehyde-3-phosphate dehydrogenase from the model plant Arabidopsis thaliana is reversed by both gluta redoxins and thioredoxins in vitro. Biochem J 445, 337-47 (2012).

38. Zaffagnini, M. et al. Redox regulation in photosynthetic organisms: foc us on gluta thionylation. Antioxid Redox Signal 16, 567-86 (2012).

39. Han, S. et al. Cytoplastic Glycera Id ehyde-3-Phosphate Dehydrogenases Interact with ATG 3 to Negatively Regula te Autophagy and Immunity in Nic otiana benthamiana. Plant Cell 27, 1316-31 (2015).

40. Guo, L. et al. Cytosolic glyceraldehyde-3-phosphate dehydrogena ses interact with phospholipase Ddelta to transduce hydrogen peroxide signals in the Arabidopsis response to stress. Plant Cell 24, 2200-12 (2012).

41. Peralta, D. et al. A proton relay enhances $\mathrm{H} 2 \mathrm{O} 2$ sensitivity of G APDH to facilita te metabolic adaptation. Nat Chem Biol 11, 156-63 (2015). 
bioRxiv preprint first posted online Feb. 15, 2019; doi: http://dx.doi.org/10.1101/545921. The copyright holder for this preprint

(which was not peer-reviewed) is the author/funder, who has granted bioRxiv a license to display the preprint in perpetuity.

All rights reserved. No reuse allowed without permission.

42. Wang, $\mathrm{H}$. et al. Proteomic analysis of early-responsive redox-sensitive proteins in Arabidopsis. J Proteome Res 11, 412-24 (2012).

43. Araki, K. et al. Redox Sensitivities of G lobal Cellular Cysteine Residues under Reductive and Oxidative Stress. J Proteome Res 15, 2548-59 (2016).

44. Hildebrandt, T., Knuesting, J ., Bemdt, C., Morgan, B. \& Sc heibe, R. Cyto solic thiol switches regulating basic cellular func tions: GAPDH as an information hub? Biol Chem 396, 523-37 (2015).

45. Zaffagnini, M. et al. Tuning Cysteine Reactivity and Sulfenic Ac id Stability by Protein Mic roenvironment in Glyceraldehyde-3-Phosphate Dehydrogenases of Arabidopsis thaliana. Antioxid Redox Signal 24, 502-17 (2016).

46. Yang, H., Yang, S., Kong, J ., Dong, A. \& Yu, S. Obta ining information a bout protein sec ondary struc tures in a queous solution using Fourier tranform IR spectrosc opy. Nat Protoc 10, 382-96 (2015).

47. Jackson, M. \& Mantsch, H.H. The use and misuse of FIR spectrosc opy in the determination of protein structure. Crit Rev Biochem Mol Biol 30, 95-120 (1995).

48. Barth, A. Infrared spec trosc opy of proteins. Biochim Biophys Acta 1767, 1073-101 (2007).

49. Seo, J. et al. An infrared spectrosc opy approach to follow beta-sheet formation in peptide a myloid a ssemblies. Nat Chem 9, 39-44 (2017).

50. Rouhier, N., Lemaire, S.D. \& J acquot, J .P. The role of gluta thione in photosynthetic orga nisms: emerging functions for gluta redoxins and glutathionylation. Annu Rev Plant Biol 59, 143-66 (2008).

51. Dixon, D.P., Skipsey, M., Grundy, N.M. \& Edwards, R. Stress-induc ed protein Sgluta thionylation in Arabidopsis. Plant Physiol 138, 2233-44 (2005).

52. Chardonnet, S. et al. First proteomic study of S-glutathionylation in cyanobacteria. J Proteome Res 14, 59-71 (2015).

53. Zaffagnini, M. et al. Glutathionylation in the photosynthetic model organism Chlamydomonas reinhardtii: a proteomic survey. Mol Cell Proteomics 11, M 111 014142 (2012).

54. Kuehne, A. et al. Acute Activation of Oxidative Pentose Phosphate Pathway as First-Line Response to Oxidative Stress in Human Skin Cells. Mol Cell 59, 359-71 (2015).

55. Chuang, D.M., Hough, C. \& Senatorov, V.V. Glyc eraldehyde-3-phosphate dehydrogenase, apoptosis, and neurodegenerative diseases. Annual Review of Pharmacology and Toxicology 45, 269-90 (2005).

56. Butterfield, D.A., Hardas, S.S. \& Lange, M.L. Oxida tively modified glycerald ehyde-3phosphate dehydrogenase (GAPDH) and Alzheimer's disea se: many pathways to neuro degeneration. J Alzheimers Dis 20, 369-93 (2010).

57. Mukai, H. et al. Fomation of morphologic ally similar globula raggregates from diverse aggregation-prone proteins in mammalian cells. Proc Natl Acad Sci U S A 102, 10887-92 (2005).

58. El Mousta ine, D., Perrer, V., Smeller, L, Lange, R. \& Torrent, J . Full-length prion protein aggregates to amyloid fibrils and spherical partic les by distinct pathways. Febs J 275, 2021-31 (2008). 
a
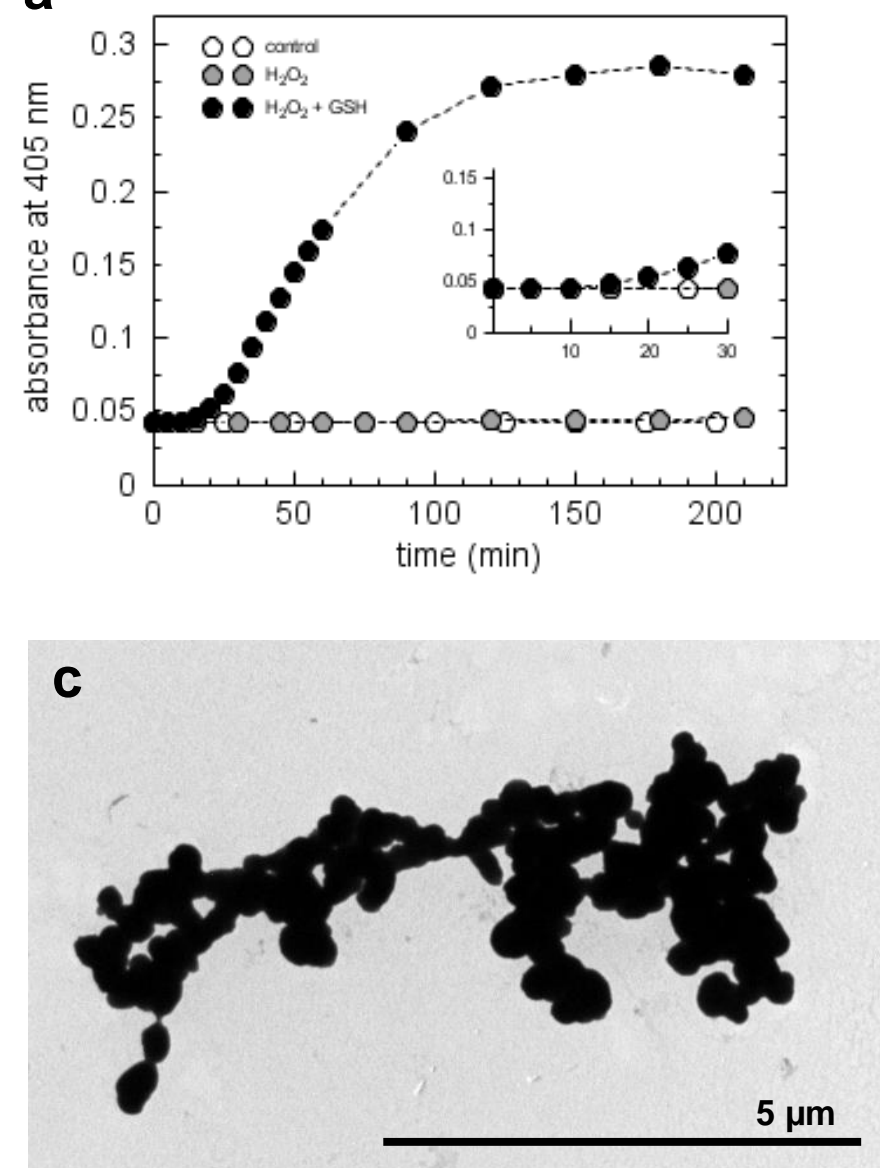

b

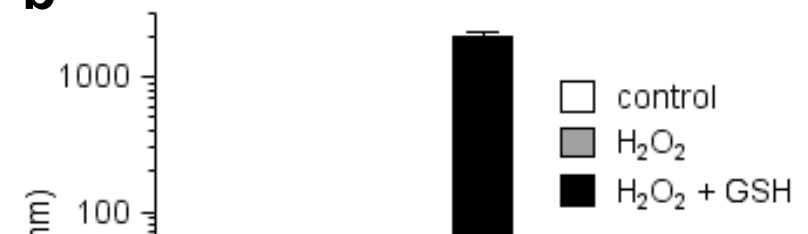

e

要

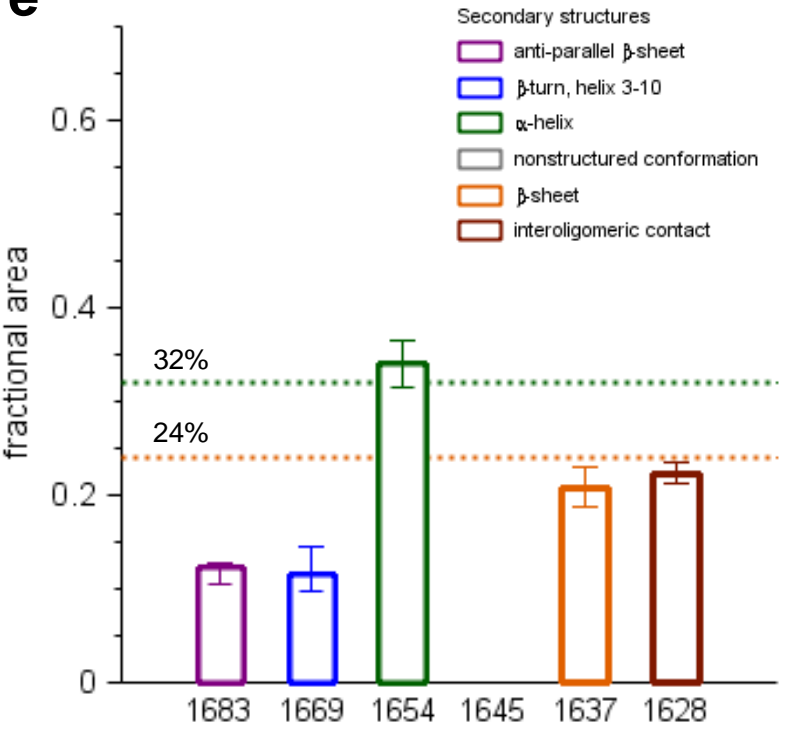

peak wavenumber $\left(\mathrm{cm}^{-1}\right)$

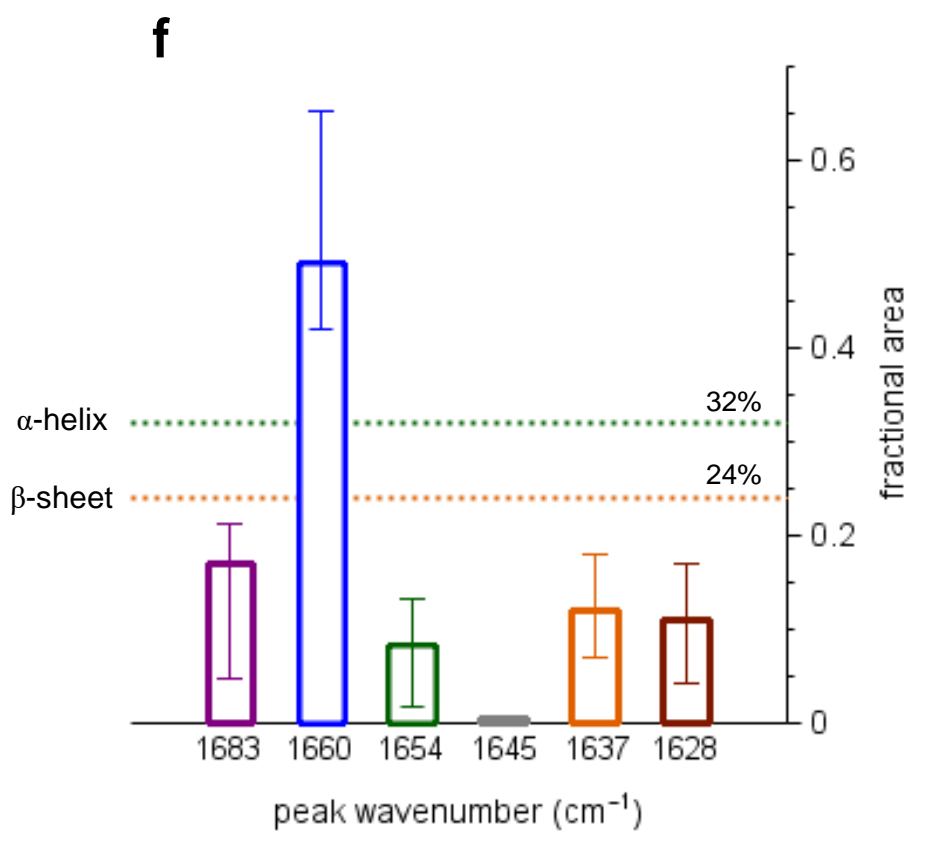


Figure 2

a

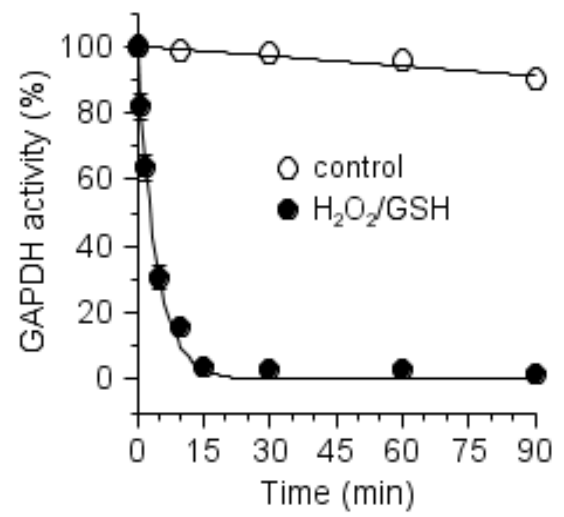

b

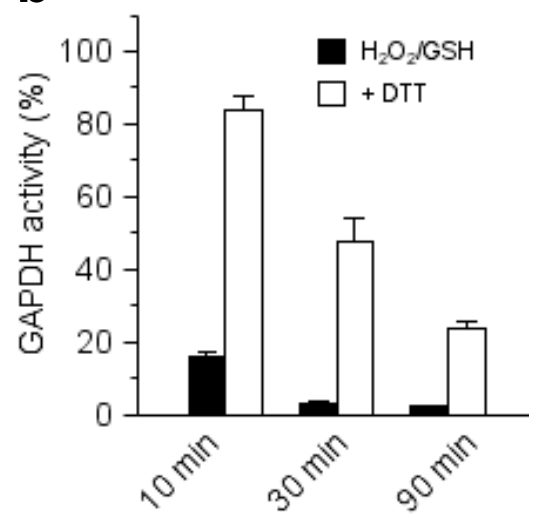

C

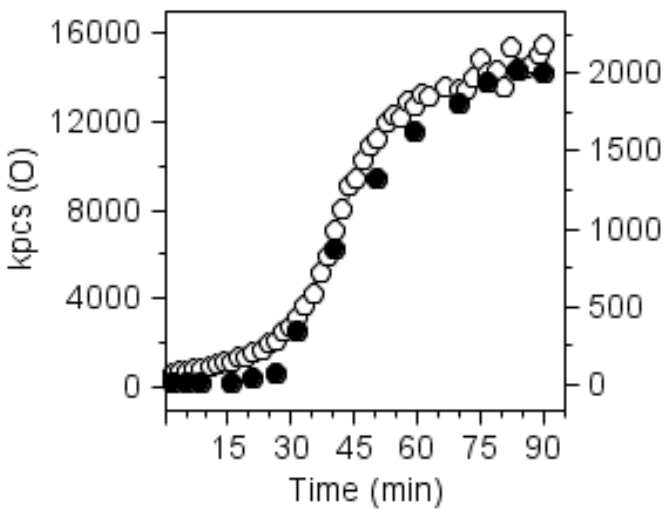

d

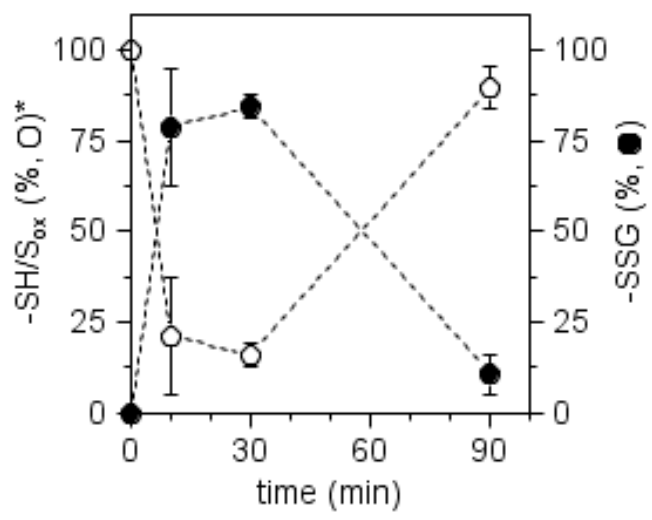

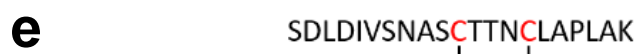

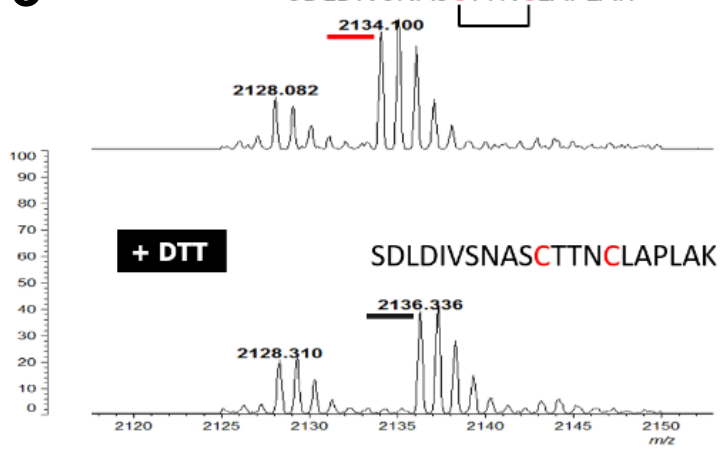


Figure 3

a

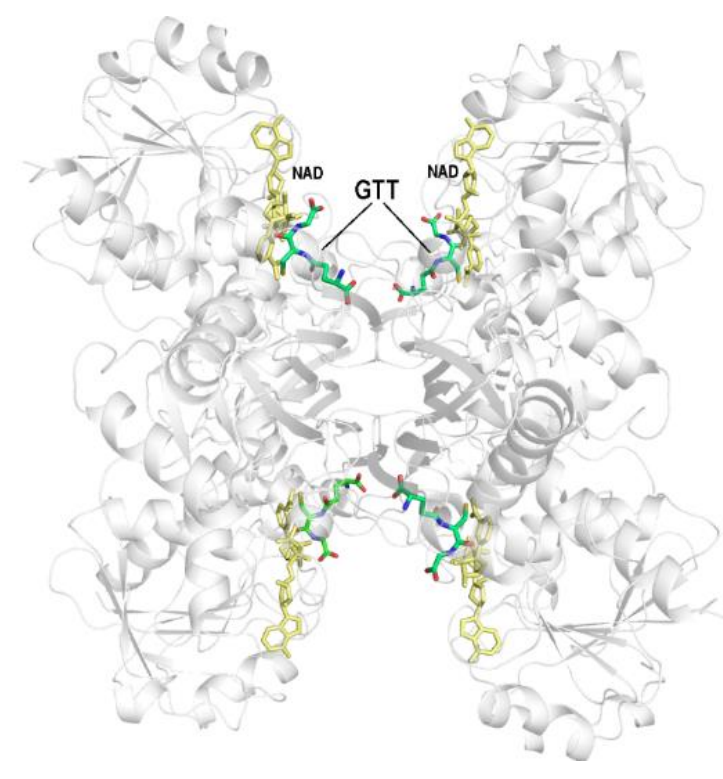

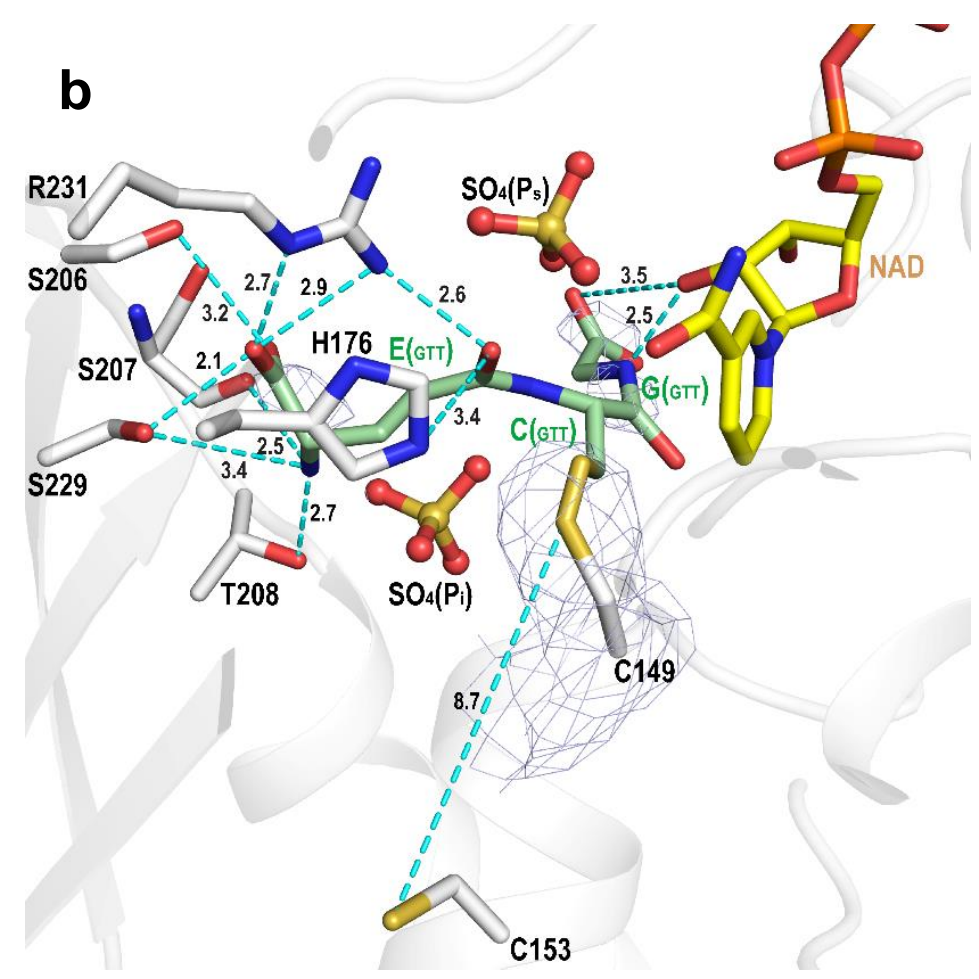

d
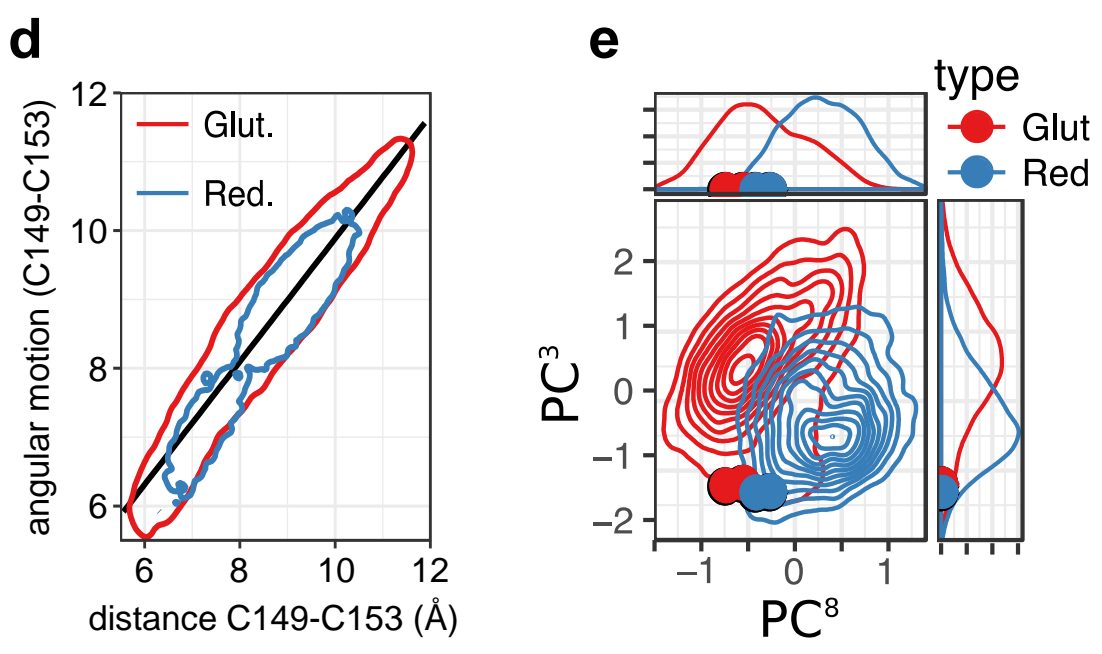

distance C149-C153 (Å)
C

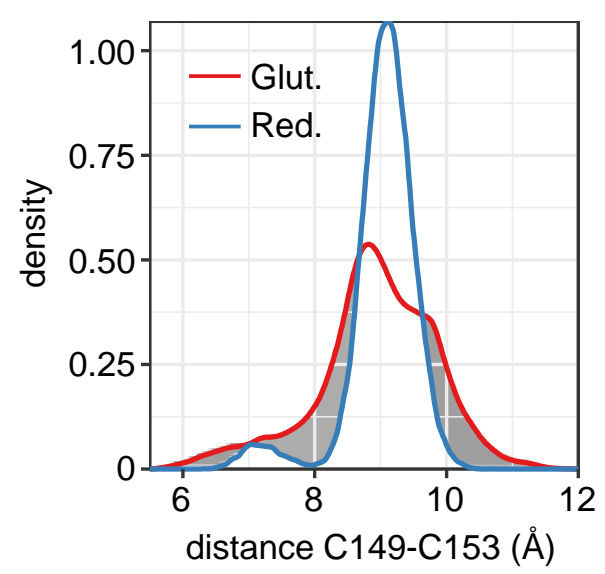


Figure 4
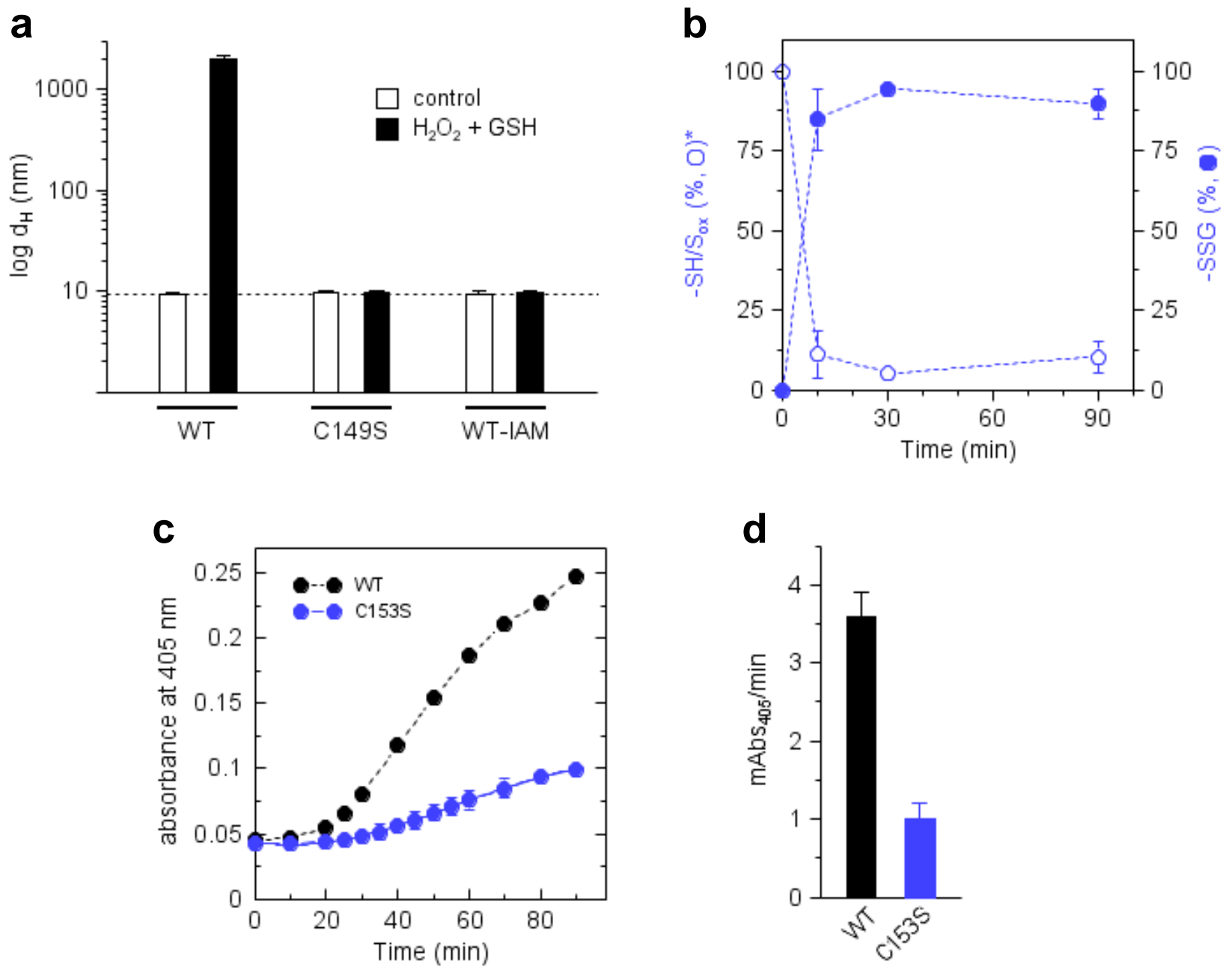

e

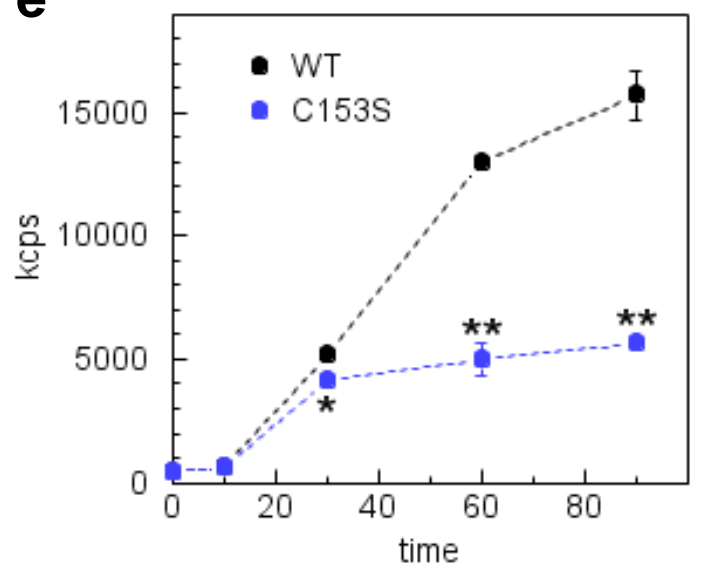

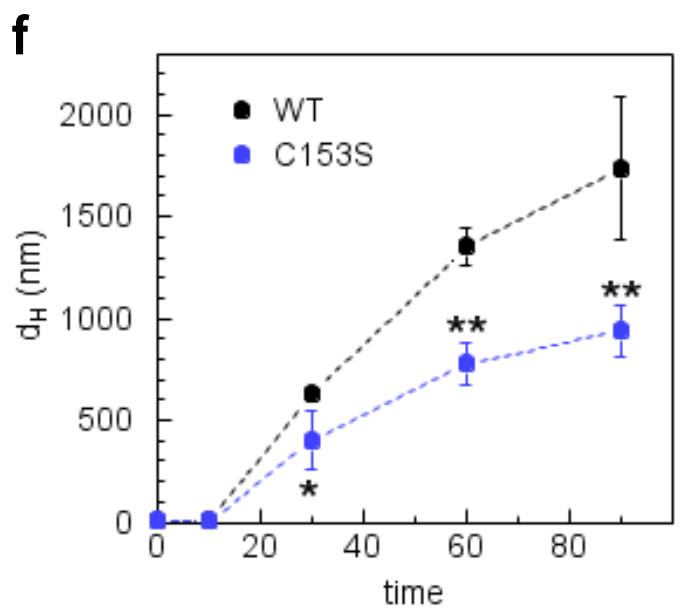

